\title{
The influence of societal behaviours and trends on mental health based applications: An environmental scan
}

Aug 4, 2021

Harshdeep Dhaliwal, ${ }^{1}$ Uzhma Nagani, ${ }^{1}$ Sindi Mukaj, ${ }^{1}$ Tommy Vo, ${ }^{2}$ Jyotsna Berry, ${ }^{3}$ Sherry Shu, ${ }^{4}$ Tuba Buyuktepe, ${ }^{5}$ Joy $\mathrm{Xu}{ }^{1}$

${ }^{1}$ McMaster University, Hamilton, ON, Canada

${ }^{2}$ Wilfrid Laurier University, Waterloo, ON, Canada

${ }^{3}$ University of British Columbia, Vancouver, BC, Canada

${ }^{4}$ St. Robert Catholic High School, Thornhill, ON, Canada

${ }^{5}$ University of Ottawa, Ottawa, ON, Canada

Contact Info: harshdeep569340@gmail.com

\begin{abstract}
BACKGROUND

Within a decade, the expeditious evolution of technology has catalyzed digital advancements employed even at one's fingertips. Now a household item, smartphones host innumerable apps supporting users across the world. One of the rising market niches includes mental-health based applications, which further branch into topics of lifestyle, habit-building, and productivity. METHODS

This systematic review explores quantitative and qualitative studies discussing variables of influence on social behaviours and trends for mental-health based applications. Searched databases include Science Direct, ProQuest, and Scopus with further supplementation of grey literature from Science Daily, Common Sense Media, and Extreme Networks. Extracted data precluded meta-analysis given the significant heterogeneity in study design, outcomes, and measurements. Studies were screened with a piloted tool and screening \& extraction was completed independently among two authors. Disagreements following reconciliation between the two authors were settled by a third author.
\end{abstract}

RESULTS

Appraised articles identified trends \& behaviors associated with app functionality, accessibility, and data/privacy security. The decline or absence of these features correlated with low user engagement.

CONCLUSION

Prevalent features were determined for enhanced functionality, accessibility, and database security, which may serve to bolster apps within mental-health and its niches.

KEYWORDS

Trends, apps, user behaviour, consumer, engagement, education, mental health, productivity, market research 


\section{INTRODUCTION}

Over a million applications, also known as apps, have been developed with the advancement of modern technology [9]. Serving a myriad of purposes, these apps target specific demographics with diverse functionalities that could lie within 1 of $24-33$ categories depending on the app store, with popular brackets in finance, lifestyle, utility, etc. The broad classifications reduce navigation-associated user confusion as the placement of apps are assorted by their main purpose $\&$ functions [32]. Within these categories, games and education-based apps account for $23.03 \%$ of all globally available apps and sum to over 400,000 apps according to recent Google Play store statistics [34]. The high volume of apps within these markets likely derive from target audience variance as multiple apps are often created under the same companies to cover several sets of demographics.

Prior to public availability and marketing, apps are created with careful consideration towards the characteristics of target demographics, including traits such as age, gender, location, education, and behaviour [15]. A process known as behavioural targeting enables user behaviours to be assessed by analyzing browser history to view searches and frequently visited websites to increase functional efficiency and user engagement [23]. Nearly all applications benefit through similar processes, but MHapps are especially attentive to these details to ensure effective support in usability without deleterious effects [10].

The National Institute of Mental Health (NIMH) classifies mental health-based apps (MHapps) into one of six categories on the basis of their function towards the consumer: self-management, cognition improvement, skills-training, social support, symptom tracking, and passive data collection [11]. Mobile apps represent an easily accessible method of delivery that requires low effort to implement with wide-spread impact on millions of users.

However, evidence on the effectiveness of apps as a low-cost mental health treatment alternative is ongoing. The Digital Mental Health Revolution Report concluded that there were at least 10, 000 mental-health based apps on the market, yet only a small percentage of these apps used effective, proven strategies supported by psychological research in order to help users with common mental health issues [31]. Research has demonstrated that the accessibility of most psychological interventions are often limited by either cost or availability of a practitioner to provide these services [11]. Therefore, the rise of MHapps may also be explained from its potential role as an alternative to in-person therapies or as a means to treat subclinical conditions that do not qualify for a diagnosis or treatment.

In a meta-analysis of nine randomized controlled trials that researched the effects of MHapps on anxiety symptoms, it was determined that users experienced a significant reduction in their anxiety after using these MHapp interventions [11]. Due to the exponential rise of smartphone users globally, increasing efficacious MHapps on phones could potentially liberate scarce 
face-to-face services in communities struggling to meet the demand by offering virtual interventions to address mild-to-moderate mental health problems [24]. This growing trend presents new opportunities for psychologists to connect with patients through mobile apps with three key benefits:

1. The therapeutic relationship between the provider and patient may be supplemented through recommended worksheets and tools outside of sessions

2. Patients may provide real-time symptom and activity monitoring to track behaviours while being reminded to use techniques learned in therapy sessions for long-term habit building

3. Patient awareness of disorders and symptoms may improve with constant logging, while also improving patient functioning through more accurate self-reporting measures [3]. The rapid increase of technological literacy elicits constant transformation of societal trends within modern society. To this extent, attitudes and trends are constantly conceived, transformed, and refined through dissemination of digital \& physical interactions across a plethora of platforms. Findings within social psychology can explain the formation and effects of trends in our applicable strata.

The initiation of societal trends and behaviours often occurs once exposure to the stimuli is made [28]. Within this notion, the affective gauge of behavioural influence on the individual is determined by elements of reason and reward. Cognitive psychology implies that an individual will seek to understand how presented stimuli such as trends apply to themselves and their lifeworld. Through this, individuals will conceptualize aspects of reason and reward of assimilating and indoctrinating these behaviours and trends [14]. Upon weighing the subjective worth of a trend to the self, one can proceed to either dismiss or execute it accordingly.

Thereby, these societal trends and behaviours also affect one's mental health through stimuli of discourse, loneliness, social pressure, jealousy, shame, and other subjective affective justifications. These themes and emotions can measure self-esteem through a mental health assessment. The individual or researcher can then discern how one's mental health is influenced by society and conjecture the individual's behaviour or engagement through closer examination of psychological, social, and environmental factors. Biological factors can not be accounted for when determining one's susceptibility or inclination to social trends and behaviours because viewers can generally not surmise the internal. However, influential thematic factors can be used to analyze and gain an inference on a subject's susceptibility to engage in social trends and behaviours. Psychological, social, and environmental factors can be broken down into entailing criteria, to deduce a subject's mentality, social paradigm, and composition [18].

Psychological factors are subjective to individual-level processes and affective states. Social factors revolve around the concept of social dynamics and designations which include: gender nuances, social class, race, ethnicity, and more. Environmental factors that affect an individual 
are found in variables that influence the subject by acting as a foundation; this can be explained through geographic culture, education, government policies, as well as environmental and demographic dynamics [1]. These thematic factors and their entailing variables can also be referenced for their impact in determining an individual's disposition towards being influenced by societal trends.

Many of these trends often arise from mental health stigma, which is often internalized by individuals. In his seminal work: Stigma: Notes on the Management of Spoiled Identity [1], Erving Goffman defines stigma as "an attribute that is deeply discrediting" that reduces an individual "from a whole and usual person to a tainted, discounted one" - similar to a spoiled identity [16, p. 3]. Mental health stigma has several implications for the social work profession, which encompasses mental health applications. In 2017, Our World in Data reported that an estimated $10.7 \%$ of the worldwide population is affected by a mental or behavioural disorder [30]. Though these conditions are highly prevalent, respective treatments have shown effectiveness in mitigating the issues to improve individual functioning in society. However, research suggests that those in need of care may not seek support, and those that do begin receiving care frequently stop prior to completion of the recommended treatment plan [12]. Plausible explanations for low participation rates in treatment may be associated with a lack of medical accessibility to diagnose or treat the condition due to a disability. The World Health Organization [38] also states that stigma is one of the greatest barriers to treatment engagement, despite it's proven effectiveness in both high and low-income countries [38]. Nevertheless, the use of mental health mobile apps to treat conditions is growing, potentially indicating a gradual shift towards a more accepting and open mentality to mental health treatments.

The purpose of this environmental scan is to examine and identify how observable trends and behaviours within society may affect user engagement for mental-health based apps. These factors are viewed in the perspective of consumers to determine the social influences on app usage. By exploring present literature, a baseline can be drawn to outline current trends and behaviours available on this topic. Marketing analysts may also use this measure to enhance product promotion as consumers often rely on social media influencers in their decision-making process [2]. Examples of enhancing product promotion include adjusting app descriptions, UI/UX design, and accessibility; all of which apply to Felicity, a productivity-based application.

The assessment of the influence of societal behaviour and trends on the usage of mental health-based apps will be used for the marketing and promotion of the Felicity App. As this app utilizes an evidence-based approach for psychological-based interventions on improving productivity in an academic setting, the findings from this environmental scan will help predict the usage behaviour of Felicity. More specifically, the environmental scan will help identify the target audience and respective features appealing to this demographic. Thereby, this app may be marketed appropriately to those most in need of its proposed mental health support. Based on the 
results of this environmental scan, social media platforms such as Instagram, TikTok, Facebook, Twitter, etc., will be used for promoting Felicity to the target audience. The use of advertisements may also be employed through platforms such as Google and Facebook ads to do the same. The analysis of consumer engagement and usage behaviour will further help in the development and finetuning of the Felicity app. Understanding how users interact with mental health-based apps will allow for the Felicity app to become more user-friendly while catering to the users' preferences. Assessing user interaction with other mental health-based apps will also help eliminate and avoid barriers that users have faced with similar apps in the past, making the Felicity app a competitive candidate among apps within this market niche.

\section{METHOD}

An environmental scan was performed to determine the influence of societal behaviour and trends on consumer usage of MHapps. The objective of this environmental scan was to search available literature to identify social trends impacting MHapp usage and engagement. Significant trends from this environmental scan will be evaluated and applied to the Felicity app after the screening and extraction of data in present literature. The selection procedure followed the Preferred Reporting Items for Systematic Review and Meta-Analyses (PRISMA) guidelines.

\section{Study Design \& Setting}

The purpose of this environmental scan is to understand how societal behaviour and trends influence the use of mental health based apps. This scan specifically focuses on assessing user engagement and behaviour when it comes to apps based on improving the mental health of their users. As the Felicity app is designed to specifically address academic productivity from a psychological perspective, the reviewed studies have a mental health and education focus. This targeted approach allows for the findings to be narrowed to the usage of apps similar to the Felicity App.

Studies were excluded for irrelevancy if there was no data concerning consumer engagement or if trends and/or behaviours were not addressed. The demographic of interest includes individuals of all genders and ethnicities located in North America, Asia, Australia, and Europe as the majority of technological users reside in these countries with devices compatible with the Felicity App. Of the global population, Asia accounts for the majority of internet usage, making up about $51.8 \%$ of internet users [7]. Furthermore, 90.3\% of North Americans use the internet on a regular basis, and $87.2 \%$ of Europeans do the same. To account for the disparities in access to the internet, countries outside of North America, Asia, Australia, and Europe were excluded. The geographical exclusion further reduces variability to ensure that the participants in the reviewed studies share similar technological backgrounds and experiences.

Furthermore, the reviewed articles were limited to the years 2011-2021 as smartphones and the use of more advanced applications became more popular than dumbphones during this time, 
largely influenced by the release of the first iPhone in 2008 [21]. Subsequently, the findings of the reviewed articles are more relevant to the Felicity App as it is a smartphone application. In addition, a mixed methods design was used for this environmental scan as it assesses both qualitative and quantitative studies to establish breadth and depth [33]. The credibility, context, and utility of the studies are assessed sufficiently when using a qualitative analysis for mixed methods data [37].

\section{Search Strategy \& Criteria}

A diverse selection of literature, which included grey literature, was reviewed based on a predetermined inclusion/exclusion criteria. The criteria was established prior to the search and validated the contextual and scientific relevance of the data by developing a standardized expectation for the literature's content and experimental purpose.

Online databases searched in this systematic review include Science Direct, Scopus, and ProQuest from June 6, 2021, to June 15, 2021, utilizing search strategies composed of key words related to the following: user engagement, mental health, behaviour, consumer, and application (refer to Appendix 1 for the search strategy). Regarding grey literature, the snowballing method was employed to identify and review the following online sources: Science Daily, Common Sense Media, and Extreme Networks. A list of keywords that were used to enhance searches include: "behaviour", "engagement", "customer", and "trends" (refer to Appendix 2). Searches were further filtered to ensure relevance based on its date of production, as studies were set within the publication date range of January 1, 2011 to June 2, 2021.

The search strategy was developed by using keywords with booleans and truncations according to the sample, phenomenon of interest, design, evaluation, and research type (SPIDER) criteria. Specifically,"engag*", "behav*", "mental health", "educat*", "customer", "consum*”, and "applic*" aided in the extraction of published literature. All of the keywords were used for a majority of our searches. A comprehensive set of sources were further processed using advanced search features to optimize relevance. Database-specific filters such as full-text, peer-reviewed, and journals were applied, when applicable. The last search was conducted on June 15, 2021.

\section{Inclusion \& Exclusion}

Eligible studies included systematic reviews, meta-analyses, non-randomized, randomized control trials (RCTs), and grey literature that were published in English between 2011 to 2021 within the field of psychology to provide a consistent baseline for searches by ensuring the relevance, accessibility, and quality of the preliminary literature. The populations of interest included general populations residing in developed countries within North America, Europe, Australia, and Asia. Since students in South America and Africa have significantly less access to the Internet and smart devices than those in the regions of interest, excluding these regions inhibited the wide discrepancy of resources from influencing the research conducted. The 
geographical exclusion created a control amongst acquired material. The focus of these studies was to explore the influence of social behaviour and trends on mental health app usage and engagement through the use of qualitative and quantitative data. Articles which were overly specific in their analysis of app effectiveness, mentioned cultural influences on app usage, and/or included studies or references unavailable online were excluded. The inclusion and exclusion criteria were predetermined. Refer to Fig. 1 for SPIDER analysis.

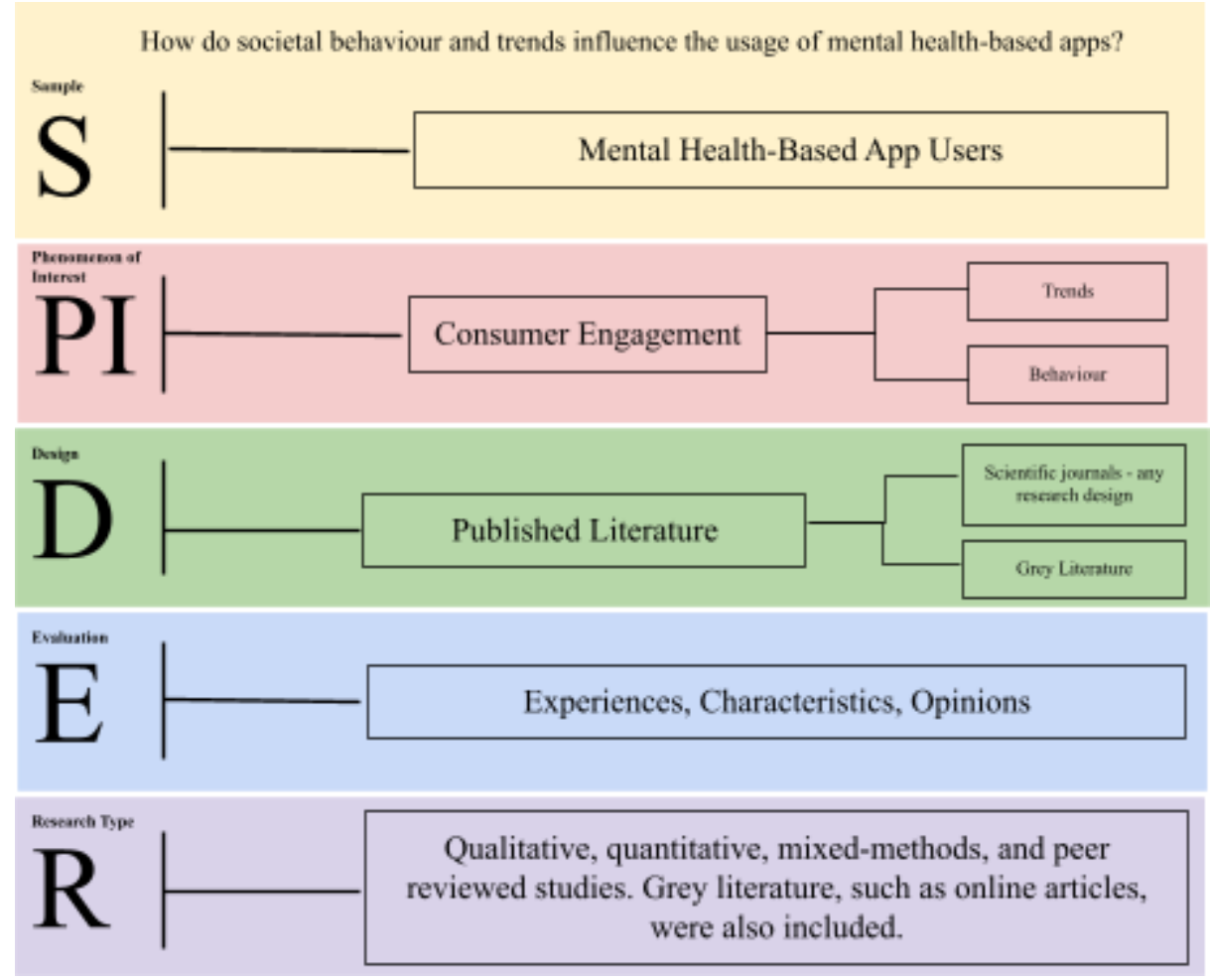

Fig. 1 Structural outline of SPIDER components that will be analyzed in this environmental scan

\section{Data Collection and Abstraction}

An abstract screening tool, consisting of 10 questions, was created and developed using the inclusion and exclusion criteria. These questions prompted the authors to analyze the literature's purpose, experimental design, methods, results, usage of consumer app engagement and societal trends, and possible applications. The database search results were combined, and duplicate articles were removed manually using Endnote (versions 8 \& 20) prior to the full text screening phase.

\section{Identification of Relevant Studies and Data Extraction}

Using the abstract screening tool, SM and JB independently reviewed 573 articles, which included study abstracts and grey literature to determine suitability of studies for inclusion. The literature was screened based on its title, abstract, and summary, when applicable. Disagreements between the two independent screeners were reconciled by a third author HD followed by the 
full-text screening of eligible literature from the abstract screening phase. The abstract and grey literature screening took place between June 16, 2021 - June 22, 2021. Duplicates were removed before full text screening. Full text screening took place between June 29, 2021 - July 2, 2021. A list of excluded studies is shown in Appendix 3.

\section{Data Extraction}

Two authors (SS and UN) independently extracted data from the finalized list of studies that met the inclusion criteria from July 6, 2021 - August 3, 2021. Data on study design, trend type, participant information, type of data collected, and significance of the trend were recorded (for study characteristics, refer to Appendix 4). The two authors resolved any disagreements during reconciliation and disagreements were resolved by a third author when necessary.

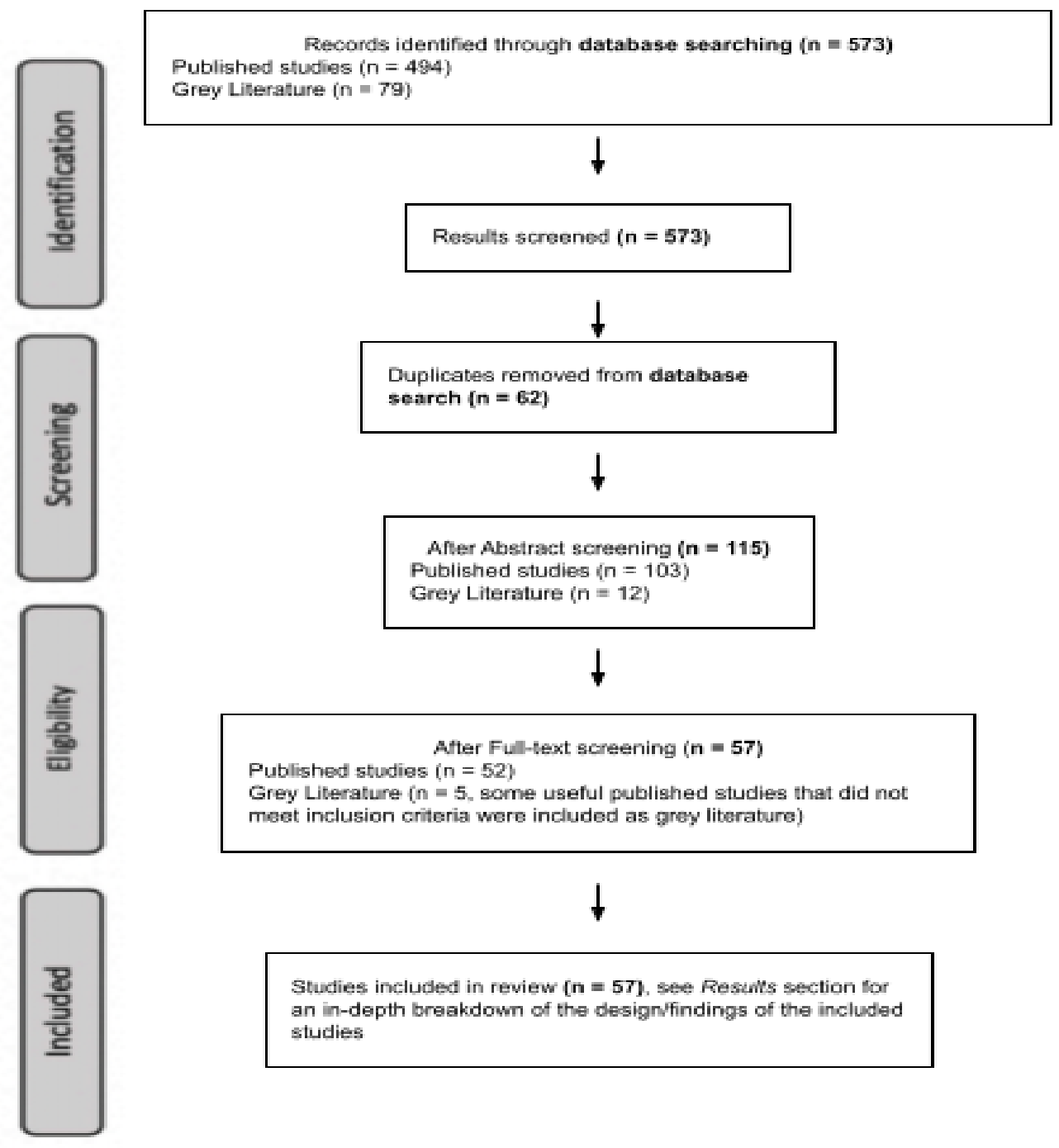

Fig. 2 Structural diagram of the completed screening and study selection processes 


\section{RESULTS}

\section{Study Selection}

The study selection and screening process is outlined in Fig. 2. 573 papers were identified from the database search; 79 were grey literature, 432 were published studies, and 62 were duplicates. Out of the 432 published studies 264 were retrieved from Science Direct, 163 from ProQuest, and 5 from Scopus. From the 79 grey literature, 34 were retrieved from Science Daily, 22 were retrieved from Common Sense Media, and 23 were retrieved from Extreme Networks. The published and grey literature articles both underwent abstract screening and full-text screening. After abstract screening, 115 articles remained, out of which 103 were published studies and 12 were grey literature. After full-text screening, a total of 57 articles were left, with 52 being published studies and 5 being grey literature.

\section{Study Characteristics}

From the 52 published studies that are included in this review, 25 are qualitative, 11 are quantitative, 16 are mixed methods. Also, of the 52 articles, 18 are observational studies, 4 are randomized control studies (RCT), 11 are literature reviews, 2 are non-randomized control studies, 2 are questionnaire-based, 4 are experimental, 6 are data analysis-based, and 5 are systematic reviews and meta-analyses. Many studies are a combination of these data types and are included in the above values. Furthemore, there were many studies that were found to be irrelevant to our research question despite meeting our inclusion criteria. From the 52 published articles, 41 were found to be relevant to our research question and 11 irrelevant.

Out of 52 published studies included, 15 were from the United States of America; 8 from Australia; 6 from the United Kingdom; 4 from Canada; 2 from China, Germany, and Spain; and 1 from Italy, Portugal, Korea, Malaysia, Denmark, the Netherlands, Ireland, Turkey, France, Slovenia, Taiwan, Bangladesh, and Japan.

\section{Findings and Outcomes}

Recent trends indicate that MHapps can improve the psychological treatment of patients, especially alongside the provision of clinical treatment. MHapps have been applied in trials to treat depression, sleep issues, anxiety, and stress, with positive self-reported results. MHapps have also helped users with mindfulness, meditation, and habit-building. The studies also displayed that users tended to prefer and consistently use apps that had a well-designed and simplistic user interface, personalized experience, and offered an array of features. The initial attitude of users toward the app also affected their engagement with the app and the benefits derived. User analytics and user data have a high potential to be incorporated into app treatments, with data privacy becoming a significant area of focus for app developers. More research regarding the effectiveness of MHapps needs to be conducted since many apps currently on the market are not based on research from well-designed studies and thus may not be effective. A summary of the findings and outcomes are located in Table 1. 
Table 1. Findings and outcomes of articles that were relevant and answered the research question

\begin{tabular}{|c|c|c|}
\hline Article & Finding & Outcome \\
\hline $\begin{array}{l}\text { McColl, L. D., et al. Peer } \\
\text { support intervention through } \\
\text { mobile application: An } \\
\text { integrative literature review and } \\
\text { future directions [25] }\end{array}$ & $\begin{array}{l}\text { Peer support based apps } \\
\text { have potential for decreasing } \\
\text { stress on individuals. }\end{array}$ & $\begin{array}{l}\text { There are positive outcomes } \\
\text { of technology based peer } \\
\text { support such as phone calls, } \\
\text { texting, and online groups. }\end{array}$ \\
\hline $\begin{array}{l}\text { White, B. K., et al. Designing } \\
\text { evaluation plans for health } \\
\text { promotion mHealth } \\
\text { interventions: a case study of } \\
\text { the Milk Man mobile man [35] }\end{array}$ & $\begin{array}{l}\text { Challenges for mHealth } \\
\text { interventions include privacy } \\
\text { and data security }\end{array}$ & $\begin{array}{l}\text { Lack of data security and } \\
\text { privacy can decrease the } \\
\text { number of app users and } \\
\text { hinder app promotion }\end{array}$ \\
\hline $\begin{array}{l}\text { Wright, C. J. C, et al. Barriers } \\
\text { and opportunities in the } \\
\text { translation of mobile phone and } \\
\text { social media interventions } \\
\text { between research and health } \\
\text { promotion practice in Australia: } \\
\text { a qualitative study of expert } \\
\text { perspectives [39] }\end{array}$ & $\begin{array}{l}\text { Translations are prioritized } \\
\text { by both researchers and } \\
\text { practitioners }\end{array}$ & $\begin{array}{l}\text { A successful app must be } \\
\text { accessible to large audiences }\end{array}$ \\
\hline $\begin{array}{l}\text { Mirzaei, T., \& Esmaeilzadeh, } P \text {. } \\
\text { Engagement in online health } \\
\text { communities: Channel } \\
\text { expansion and social exchanges } \\
\text { [26] }\end{array}$ & $\begin{array}{l}\text { Patient willingness to share } \\
\text { and seek information is } \\
\text { affected by health status }\end{array}$ & $\begin{array}{l}\text { Social support may increase } \\
\text { members' engagement and } \\
\text { information exchange in } \\
\text { OHCs }\end{array}$ \\
\hline $\begin{array}{l}\text { Bauer, M., et al. Smartphones in } \\
\text { mental health: a critical review } \\
\text { of background issues, current } \\
\text { status and future concerns [5] }\end{array}$ & $\begin{array}{l}\text { Patients prefer different } \\
\text { types of consumer } \\
\text { technologies }\end{array}$ & $\begin{array}{l}\text { Psychiatry based technology } \\
\text { should focus on automating } \\
\text { functions that will provide } \\
\text { patients with a variety of } \\
\text { methods to access and use } \\
\text { the technology to best fit the } \\
\text { patients' lifestyles and } \\
\text { budget }\end{array}$ \\
\hline $\begin{array}{l}\text { Birkmeyer, S., et al. } \\
\text { Determinants of mHealth } \\
\text { success: An empirical } \\
\text { investigation of the user } \\
\text { perspective [6] }\end{array}$ & $\begin{array}{l}\text { User satisfaction has a } \\
\text { strong positive influence on } \\
\text { the continuous usage of } \\
\text { MHapps }\end{array}$ & $\begin{array}{l}\text { User's general attitude } \\
\text { towards mHealth over all } \\
\text { affects the success of the app }\end{array}$ \\
\hline Li, M., et al. Meaningful & The use of a visual impact & Gamified psychological \\
\hline
\end{tabular}




\begin{tabular}{|c|c|c|}
\hline $\begin{array}{l}\text { gamification for psychological } \\
\text { empowerment: exploring user } \\
\text { affective experience mirroring } \\
\text { in a psychological self-help } \\
\text { system [22] }\end{array}$ & $\begin{array}{l}\text { metaphor-based (VIM) } \\
\text { system was considered more } \\
\text { empowering, allowing users } \\
\text { to gain more control over } \\
\text { their emotional well-being. }\end{array}$ & $\begin{array}{l}\text { self-help systems that could } \\
\text { echo the user's facial } \\
\text { expressions in real time are } \\
\text { efficient. }\end{array}$ \\
\hline $\begin{array}{l}\text { Bucci, S., et al. Early Psychosis } \\
\text { Service User Views on Digital } \\
\text { Technology: Qualitative } \\
\text { Analysis [8] }\end{array}$ & $\begin{array}{l}\text { DHIs were perceived as } \\
\text { destigmatizing, overcoming } \\
\text { barriers of traditional } \\
\text { interventions, facilitating } \\
\text { communication and } \\
\text { empowering to users. }\end{array}$ & $\begin{array}{l}\text { Users believed DHIs to be a } \\
\text { progressive and modern } \\
\text { platform to help with mental } \\
\text { support. Some users were } \\
\text { concerned about having } \\
\text { privacy and data security } \\
\text { being breached }\end{array}$ \\
\hline $\begin{array}{l}\text { Qu, C., et al. Functionality of } \\
\text { Top-Rated Mobile Apps for } \\
\text { Depression: Systematic Search } \\
\text { and Evaluation [29] }\end{array}$ & $\begin{array}{l}\text { Available apps for } \\
\text { depression provide a wide } \\
\text { array of functionality in } \\
\text { order to help users across a } \\
\text { range of age group }\end{array}$ & $\begin{array}{l}\text { Need for guidelines to } \\
\text { ensure that privacy and } \\
\text { safety are protected while } \\
\text { using the apps. }\end{array}$ \\
\hline $\begin{array}{l}\text { Hartin, P. J., et al. The } \\
\text { Empowering Role of Mobile } \\
\text { Apps in Behavior Change } \\
\text { Interventions: The Gray Matters } \\
\text { Randomized Controlled Trial } \\
\text { [17] }\end{array}$ & $\begin{array}{l}\text { Increased app exposure had } \\
\text { a significant effect on } \\
\text { clinical measurements }\end{array}$ & $\begin{array}{l}\text { Promoting apps to } \\
\text { clinicians/professionals } \\
\text { increases the app's success }\end{array}$ \\
\hline $\begin{array}{l}\text { Mitchell, M., et al. Uptake of an } \\
\text { Incentive-Based mHealth App: } \\
\text { Process Evaluation of the Carrot } \\
\text { Rewards App [27] }\end{array}$ & $\begin{array}{l}\text { Findings show that loyalty } \\
\text { points may promote the } \\
\text { usage of mHealth apps } \\
\text { among female users }\end{array}$ & $\begin{array}{l}\text { The use of incentives in } \\
\text { promoting healthy habits is a } \\
\text { possibility for the future }\end{array}$ \\
\hline $\begin{array}{l}\text { Widnall, E., et al. User } \\
\text { Perspectives of } \\
\text { Mood-Monitoring Apps } \\
\text { Available to Young People: } \\
\text { Qualitative Content Analysis } \\
\text { [36] }\end{array}$ & $\begin{array}{l}\text { Findings show that users } \\
\text { prefer apps that personalize } \\
\text { their needs, have a simple } \\
\text { design, have an accurate } \\
\text { representation and review of } \\
\text { fluctuating moods }\end{array}$ & $\begin{array}{l}\text { Eight themes discovered in } \\
\text { positive user reviews } \\
\text { include accessibility, } \\
\text { flexibility, recording and } \\
\text { representation of mood, user } \\
\text { requests, reflecting on } \\
\text { mood, technical features, } \\
\text { design and health promotion }\end{array}$ \\
\hline $\begin{array}{l}\text { Dennison, L., et al. } \\
\text { Opportunities and Challenges } \\
\text { for Smartphone Applications in } \\
\text { Supporting Health Behavior } \\
\text { Change: Qualitative Study [13] }\end{array}$ & $\begin{array}{l}\text { Participants believed that } \\
\text { accuracy and legitimacy, } \\
\text { security, effort required, and } \\
\text { immediate effects on mood } \\
\text { would affect their app usage }\end{array}$ & $\begin{array}{l}\text { Improving the identified } \\
\text { factors can increase user } \\
\text { engagement (i.e. increase } \\
\text { ability to record and track } \\
\text { behavior, as well as record } \\
\text { goals and learn new }\end{array}$ \\
\hline
\end{tabular}




\begin{tabular}{|l|l|l|}
\hline & information) \\
\hline $\begin{array}{l}\text { Zhao, J., et al. Can Mobile } \\
\text { Phone Apps Influence People's } \\
\text { Health Behavior Change? An } \\
\text { Evidence Review [40] }\end{array}$ & $\begin{array}{l}\text { Found that too much } \\
\text { interaction can inhibit } \\
\text { positive health behaviours } \\
\text { and that there is a lack of } \\
\text { dynamic tailoring, } \\
\text { interactive education, and } \\
\text { self-monitoring } \\
\text { interventions }\end{array}$ & $\begin{array}{l}\text { Some features make apps } \\
\text { better, such as less time } \\
\text { consumption, user-friendly } \\
\text { design, real-time feedback, } \\
\text { individualized elements, } \\
\text { detailed information, and } \\
\text { health professional } \\
\text { involvement. }\end{array}$ \\
\hline $\begin{array}{l}\text { Hicks, J. L., et al. Best practices } \\
\text { for analyzing large-scale health } \\
\text { data from wearables and } \\
\text { smartphone apps [19] }\end{array}$ & $\begin{array}{l}\text { Men are affected by the } \\
\text { performance of other men } \\
\text { and women, but women are } \\
\text { affected only by the } \\
\text { performance of other women }\end{array}$ & $\begin{array}{l}\text { 75\% of users re-engage with } \\
\text { apps after extended periods } \\
\text { of dormancy and are more } \\
\text { interactive with apps when } \\
\text { networked with opposite sex } \\
\text { users }\end{array}$ \\
\hline $\begin{array}{l}\text { Aydin, G., \& Silahtaroglu, G. } \\
\text { Insights into mobile health } \\
\text { application market via a content } \\
\text { analysis of marketplace data } \\
\text { with machine learning [4] }\end{array}$ & $\begin{array}{l}\text { Apps that mention a privacy } \\
\text { policy or provide videos in } \\
\text { description lead to higher } \\
\text { user scores. Free apps with } \\
\text { in-app purchase possibilities, } \\
\text { (social networking, sharing } \\
\text { features, and feedback } \\
\text { mechanisms lead to higher } \\
\text { number of downloads }\end{array}$ & $\begin{array}{l}\text { In-app purchases, increased } \\
\text { privacy, and high } \\
\text { accessibility increase user } \\
\text { ratings and engagement }\end{array}$ \\
\hline $\begin{array}{l}\text { Iowa State University. Mobile } \\
\text { apps and online reviews } \\
\text { influence consumer behavior } \\
\text { [20] }\end{array}$ & $\begin{array}{l}\text { More than half of apps } \\
\text { downloaded are deleted after } \\
\text { one use }\end{array}$ & $\begin{array}{l}\text { Product reviews and social } \\
\text { media posts have an impact } \\
\text { on the perception of apps } \\
\text { and its brand }\end{array}$ \\
\hline
\end{tabular}

\section{DISCUSSION}

This environmental scan provides an in-depth analysis of the societal trends and behaviours that are present in current literature, with regard to mental health-based app usage. The data, which consists of observational, qualitative, mix-method, quantitative, experimental, systematic review, and self-report measures, suggests that trends and behaviours are dictated by several factors. The majority of studies ( $n=17)$ mentioned data security, app functionality, and accessibility to be areas of concern for mental health-based app users (refer to appendix 4). Therefore, the reduction and improvement of these issues into the Felicity App will be assessed. 


\section{Data Security}

Challenges for mHealth interventions include privacy and data security. Due to the sharing of health history and personal information on such apps, the lack of data security and privacy can decrease the number of app users and hinder app promotion. Numerous studies $(n=8)$ discussed privacy and data security within the app because users were worried about personal data breaches. To eliminate such concerns, several data security controls can be embedded to provide a greater sense of security to concerned users and increase consumer attraction. These controls can include enabling data encryption or data masking software, which would provide more confidentiality since data becomes difficult to read for unauthorized users. Besides integrating these controls into its app designs, Felicity can also mention its privacy policy through marketing measures to increase app users [4]. Ensuring data privacy and security will benefit Felicity since consumers are more likely to engage and be attracted to applications with secure databases.

\section{App Functionality}

Multiple studies $(\mathrm{n}=7)$ displayed a correlation between engagement and app design. For instance, users are more likely to engage with apps that mimic the layout or style of popular apps. User satisfaction also has a strong positive influence on the continuous usage of mHealth apps. Since social networking, sharing features, and feedback mechanisms, are implemented for higher user engagement because of social media's influence on modern society. Findings further showed that users prefer personalizable apps that are simple in design, have an accurate representation, and range of moods. Moreover, improving factors, such as the ability to record and track behavior, record goals, and learn new information can increase user engagement. Accordingly, Felicity will ensure that the application includes accessibility, flexibility, representation of mood, user requests, technical features, design, and health promotion, for user satisfaction.

\section{Accessibility}

Translating mobile phone and social media interventions, including mHealth applications, is prioritized by researchers and practitioners $(n=2)$. It is a necessary component for the advancement of research, health promotion, and applications since a successful app must be accessible to large audiences. For this reason, as a mental health aid application, Felicity will be translated into French, Spanish, Arabic, and Turkish to cater to a broader audience. Since mental health is not limited to a single nation or country but an issue across continents, Felicity will aim to expand its translations to reach global communities. Additional languages may be added in the future, depending on the application's growth.

\section{Strengths and Limitations}

There were some limitations to the environmental scan conducted. Firstly, a limited amount of useful grey literature was found through the scan which fit the inclusion and exclusion criteria 
provided, and explored the use of mental health-based apps. Grey-literature can be useful in obtaining research which can give in-depth information on the topics being explored.

Another limitation was the lack of accessible peer-reviewed research in the field. Since mental-health based apps are a part of an up-and-coming market, there is a limited number of research articles that have been published so far. Until further research is conducted on the practicality and effectiveness of these apps relative to more traditional treatment methods, its usefulness remains provisional and subject to change in the future. In addition, it was difficult to find research articles and grey literature that disclosed all the criteria outlined in the Screening Tool. In the Full-Text Screening process, it became apparent that important information, such as therapeutic intervention used or size of treatment population, were not being stated in the research articles.

The environmental scan includes studies from North America, Europe, Australia, and Asia. There were a total of 21 studies from North America, 17 from Europe, 8 from Australia, and 8 from Asia. Data were extracted from several countries within these regions to understand the influence of social and behavioural trends on mental health-based applications. The included studies were limited to the regions listed above to have an accurate representation of the targeted population for the Felicity App. However, studies that were in any language other than English were excluded from the environmental scan, thus limiting the scope of the literature collection.

Another limitation is the lack of longitudinal studies that researched the long-term effects of social trends and behaviours on mental health-based applications. The majority of the included studies ranged from a few hours to a month. However, many studies theorized that mental health-based applications will increase in popularity in the future.

\section{CONCLUSION}

The demand for virtual mental health-based apps is evident in the rise of app downloads to phones and other electronic devices. However, only a small portion of available apps on the current market are effective treatments for mental health issues, signifying that there is room for developing novel apps backed by research for proven psychological techniques and strategies. Hence, an environmental scan was performed to analyze the trends and behaviours that influence digital mental health-based apps user engagement. By implementing subtle improvements, such as creating a stronger user interface, improving data safety, and increasing app accessibility and services, app developers, such as Felicity, can design an app to be an effective mental health tool for its users. These results were identified in 17 studies and can be used in the future marketing and promotion of the Felicity App in June 2022. 


\section{REFERENCES}

[1] Alegría, M., NeMoyer, A., Falgàs Bagué, I., Wang, Y., \& Alvarez, K. (2018, September 17). Social Determinants of Mental Health: Where We Are and Where We Need to Go. Current psychiatry reports, 20(11), 95. https://doi.org/10.1007/s11920-018-0969-9

[2] Andjelic, A. (2021, March 2). Social Influence. Ana Andjelic. https://andjelicaaa.medium.com/social-influence-2b137f932140

[3] APA Practice Organization. (2015, September). Benefits and Risks of Apps. American Psychological Association Services, Inc. https://www.apaservices.org/practice/good-practice/mobile-behavioral-apps.pdf

[4] Aydin, G., \& Silahtaroglu, G. (2021, January 6). Insights into mobile health application market via a content analysis of marketplace data with machine learning. PloS one, 16(1), e0244302. https://doi.org/10.1371/journal.pone.0244302

[5] Bauer, M., Glenn, T., Geddes, J., Gitlin, M., Grof, P., Kessing, L. V., Monteith, S., Faurholt-Jepsen, M., Severus, E., \& Whybrow, P. C. (2020, January 10). Smartphones in mental health: a critical review of background issues, current status and future concerns. International journal of bipolar disorders, 8(1), 2. https://doi.org/10.1186/s40345-019-0164-X

[6] Birkmeyer, S., Wirtz, B.W., \& Langer, P. (2021, August). Determinants of mHealth success: An empirical investigation of the user perspective. Int. J. Inf. Manag., 59, 102351. https://doi.org/10.1016/j.ijinfomgt.2021.102351

[7] Broadband Search. (n.d.). Key Internet Statistics to Know in 2021(Including Mobile). Broadband Search. https://www.broadbandsearch.net/blog/internet-statistics\#post-navigation-0

[8] Bucci, S., Morris, R., Berry, K., Berry, N., Haddock, G., Barrowclough, C., Lewis, S., \& Edge, D. (2018, October 31). Early Psychosis Service User Views on Digital Technology: Qualitative Analysis. JMIR mental health, 5(4), e10091. https://doi.org/10.2196/10091

[9] Buildfire. (n.d.). Mobile App Download and Usage Statistics (2021). Buildfire. https://buildfire.com/app-statistics/

[10] Bulatovych, D. (n.d.). Aspects to Consider When Developing a Mental Health App. Yalantis. https://yalantis.com/blog/mental-health-app-development/

[11] Chandrashekar, P. (2018, March 23). Do mental health mobile apps work: evidence and recommendations for designing high-efficacy mental health mobile apps. mHealth, 4, 6 . https://doi.org/10.21037/mhealth.2018.03.02

[12] Corrigan, P. (2004, October 1). How stigma interferes with mental health care. The American psychologist, 59(7), 614-625. https://doi.org/10.1037/0003-066X.59.7.614 
[13] Dennison, L., Morrison, L., Conway, G., \& Yardley, L. (2013, April 18). Opportunities and challenges for smartphone applications in supporting health behavior change: qualitative study. Journal of medical Internet research, 15(4), e86. https://doi.org/10.2196/jmir.2583

[14] Domjan, M. (1998). The principles of learning and behavior (4th ed.). Thomson Brooks/Cole Publishing Co.

[15] Genie. (2019, June 24). How to Find Your Target Audience for Mobile Apps. App Radar. https://appradar.com/blog/how-to-find-your-target-audience-for-mobile-apps

[16] Goffman, E. (1963). Stigma: Notes on the Management of Spoiled Identity. Englewood Cliffs NJ: Prentice Hall.

[17] Hartin, P. J., Nugent, C. D., McClean, S. I., Cleland, I., Tschanz, J. T., Clark, C. J., \& Norton, M. C. (2016, August 2). The Empowering Role of Mobile Apps in Behavior Change Interventions: The Gray Matters Randomized Controlled Trial. JMIR mHealth and uHealth, 4(3), e93. https://doi.org/10.2196/mhealth.4878

[18] HealthyPeople. (n.d.). Mental Health. HealthyPeople. https://www.healthypeople.gov/2020/leading-health-indicators/2020-lhi-topics/Mental-Heal $\underline{\text { th/determinants }}$

[19] Hicks, J. L., Althoff, T., Rok, S., Kuhar, P., Bojan, B., King, A. C., Leskovec, J., \& Delp, S. L. (2019, June 3). Best practices for analyzing large-scale health data from wearables and smartphone apps. NPJ Digital Medicine, 2(1). https://doi.org/10.1038/s41746-019-0121-1

[20] Iowa State University. (2015, September 30). Mobile apps and online reviews influence consumer behavior. Iowa State University News Service. https://www.news.iastate.edu/news/2015/09/30/mobileapps

[21] Jackson, K. (2018, July 25). A brief history of the smartphone. Science Node. https://sciencenode.org/feature/How $\% 20 \mathrm{did} \% 20$ smartphones $\% 20$ evolve.php

[22] Li, M., Chau, P., \& Ge, L. (2021, February). Meaningful gamification for psychological empowerment: exploring user affective experience mirroring in a psychological self-help system. Internet Res., 31(1), 11-58. https://doi.org/10.1108/INTR-02-2020-0094

[23] Lotame. (2018, September 17). What Is Behavioral Targeting? Lotame. lotame.com/what-is-behavioral-targeting/

[24] Marshall, J. M., Dunstan, D. A., \& Bartik, W. (2020). Effectiveness of Using Mental Health Mobile Apps as Digital Antidepressants for Reducing Anxiety and Depression: Protocol for a Multiple Baseline Across-Individuals Design. JMIR research protocols, 9(7), e17159. https://doi.org/10.2196/17159

[25] McColl, L. D., Rideout, P. E., Parmar, T. N., \& Abba-Aji, A. (2014, August 15). Peer support intervention through mobile application: An integrative literature review and future directions. Canadian Psychology/Psychologie canadienne, 55(4), 250-257. https://psycnet.apa.org/doi/10.1037/a0038095 
[26] Mirzaei, T., \& Esmaeilzadeh, P. (2021, January). Engagement in online health communities: Channel expansion and social exchanges. Information \& Management, 58(1). https://doi.org/10.1016/j.im.2020.103404

[27] Mitchell, M., White, L., Oh, P., Alter, D., Leahey, T., Kwan, M., \& Faulkner, G. (2017, May 30). Uptake of an Incentive-Based mHealth App: Process Evaluation of the Carrot Rewards App. JMIR mHealth and uHealth, 5(5), e70. https://doi.org/10.2196/mhealth.7323

[28] Myers, D. G. (2010). Social Psychology (10th ed.). McGraw-Hill.

[29] Qu, C., Sas, C., Daudén Roquet, C., \& Doherty, G. (2020, January 24). Functionality of Top-Rated Mobile Apps for Depression: Systematic Search and Evaluation. JMIR mental health, 7(1), e15321. https://doi.org/10.2196/15321

[30] Ritchie, H., \& Roser, M. (2018, April). Mental Health. Our World in Data. https://ourworldindata.org/mental-health

[31] Roland, J., Lawrance, E., Insel, T., \& Christensen, H. (2020, November). The Digital Mental Health Revolution: Transforming Care Through Innovation and Scale-Up. Wish. https://2020.wish.org.qa/app/uploads/2020/09/IMPJ7849-03-Digital-Mental-Health-WISH2 020-201103-WEB.pdf

[32] Rosul, D. (2021, June 15). What are the popular types and categories of apps. ThinkMobiles. https://thinkmobiles.com/blog/popular-types-of-apps/

[33] Schoonenboom, J., \& Johnson, R. B. (2017, July 5). How to Construct a Mixed Methods Research Design. Kolner Zeitschrift fur Soziologie und Sozialpsychologie, 69(Suppl 2), 107-131. https://doi.org/10.1007/s11577-017-0454-1

[34] Statista Research Department. (2021, July 6). Most popular Google Play app categories as of 1st quarter 2021, by share of available apps. Statista. https://www.statista.com/statistics/279286/google-play-android-app-categories/

[35] White, B. K., Burns, S. K., Giglia, R. C., \& Scott, J. A. (2016, October 26). Designing evaluation plans for health promotion mHealth interventions: a case study of the Milk Man mobile app. Health promotion journal of Australia : official journal of Australian Association of Health Promotion Professionals, 27(3), 198-203. https://doi.org/10.1071/HE16041

[36] Widnall, E., Grant, C. E., Wang, T., Cross, L., Velupillai, S., Roberts, A., Stewart, R., Simonoff, E., \& Downs, J. (2020, October 8). User Perspectives of Mood-Monitoring Apps Available to Young People: Qualitative Content Analysis. JMIR mHealth and uHealth, 8(10), e18140. https://doi.org/10.2196/18140

[37] Wisdom, J., \& Creswell, J. W. (2013, February). Mixed Methods: Integrating Quantitative and Qualitative Data Collection and Analysis While Studying Patient-Centered Medical Home Models. Agency for Healthcare Research and Quality. AHRQ Publication No. 13-0028-EF. 
[38] World Health Organization. (2001). The World health report : 2001 : Mental health : new understanding, new hope. World Health Organization.

https://www.who.int/whr/2001/en/whr01 en.pdf

[39] Wright, C. J. C, Schwarzman, J., Dietze, P. M., Crockett, B., \& Lim, M. (2019, January 10). Barriers and opportunities in the translation of mobile phone and social media interventions between research and health promotion practice in Australia: a qualitative study of expert perspectives. Health research policy and systems, 17(1), 5. https://doi.org/10.1186/s12961-018-0406-X

[40] Zhao, J., Freeman, B., \& Li, M. (2016, October 31). Can Mobile Phone Apps Influence People's Health Behavior Change? An Evidence Review. Journal of medical Internet research, 18(11), e287. https://doi.org/10.2196/jmir.5692 


\section{DECLARATIONS}

\section{Funding:}

Funding: This systematic review was funded in part by a grant from The Duke of Edinburgh's International Award through the P2P program and in partnership with the federal government of Canada.

\section{Conflicts of interest/Competing interests:}

The authors declared no potential conflicts of interest with respect to the research, authorship, and/or publication of this article.

\section{Availability of data and material:}

Available upon request.

\section{Abbreviations:}

mHealth: Mobile Health

RCT: Randomized Control Trial

MHapp: Mental Health-Based app

\section{Code availability:}

N/A

\section{Authors' contributions:}

HD and UN conceptualized the environmental scan and designed the protocol. HD, JB, SM, SS, TV, and UN conducted the database search. JB and SM completed preliminary and full-text screenings, SS and UN completed the data extraction and analysis. HD created figures and computed numerical data. HD, JB, SM, SS, TB, TV, and UN equally wrote the manuscript. JX underwent several rounds of revisions, secured funding acquisition and managed the publishing process. All authors reviewed the final manuscript.

\section{Appendix 1}

\section{Database Searches}

June 6, 2021 to June 15, 2021

\begin{tabular}{|l|l|l|}
\hline Database & Search & Results \\
\hline Science Direct & "personal" AND "behav" AND "consumer" OR "customer" & 264 \\
& $\begin{array}{l}\text { AND "usage" AND "mental health" AND "application" AND } \\
\text { "engagement" }\end{array}$ & \\
\hline
\end{tabular}




\begin{tabular}{|l|l|l|}
\hline Scopus & $\begin{array}{l}\text { "consumer" OR "customer" AND "usage" AND "mental } \\
\text { health" AND "application" AND "engagement" }\end{array}$ & 5 \\
\hline ProQuest & $\begin{array}{l}\text { trends AND behaviour AND (user engagement) AND } \\
\text { consumer AND app AND (mental health) AND usage }\end{array}$ & 163 \\
\hline
\end{tabular}

\section{Appendix 2}

\section{Grey Literature Searches}

June 15, 2021

\begin{tabular}{|l|l|l|}
\hline Database & Search & Results \\
\hline Science Daily & $\begin{array}{l}\text { affect AND behaviour AND usage AND customer AND } \\
\text { engagement }\end{array}$ & 34 \\
\hline $\begin{array}{l}\text { Common Sense } \\
\text { Media }\end{array}$ & $\mathrm{n} / \mathrm{a}$ & 22 \\
\hline Extreme Networks & user engagement trends app and educate & 23 \\
\hline
\end{tabular}

\section{Appendix 3}

\section{List of Excluded Files from Full Text Screening}

\begin{tabular}{|l|l|}
\hline Author & Title \\
\hline Yuliando, H., \& Purnasari, H. & $\begin{array}{l}\text { How Relationship Quality on Customer Commitment } \\
\text { Influences Positive e-WOM }\end{array}$ \\
\hline Schnall, R., et al. & $\begin{array}{l}\text { Efficacy, Use, and Usability of the VIP-HANA App for } \\
\text { Symptom Self-management in PLWH with HANA Conditions }\end{array}$ \\
\hline Zhang, Q., et al. & $\begin{array}{l}\text { Measurement and Assessment of Physical Activity by } \\
\text { Information and Communication Technology }\end{array}$ \\
\hline Attwood, S., et al. & $\begin{array}{l}\text { Using a mobile health application to reduce alcohol } \\
\text { consumption: a mixed-methods evaluation of the drinkaware } \\
\text { track \&amp; calculate units application }\end{array}$ \\
\hline & $\begin{array}{l}\text { Balanced: a randomised trial examining the efficacy of two } \\
\text { self-monitoring methods for an app-based multi-behaviour } \\
\text { intervention to improve physical activity, sitting and sleep in } \\
\text { adults }\end{array}$ \\
\hline
\end{tabular}




\begin{tabular}{|c|c|}
\hline Ahmad, N. A., et al. & $\begin{array}{l}\text { Willingness, perceived barriers and motivators in adopting } \\
\text { mobile applications for health-related interventions among } \\
\text { older adults: a scoping review protocol }\end{array}$ \\
\hline Beames, J. R., et al. & $\begin{array}{l}\text { Protocol for the process evaluation of a complex intervention } \\
\text { delivered in schools to prevent adolescent depression: the } \\
\text { Future Proofing Study }\end{array}$ \\
\hline Matthews, L., et al. & $\begin{array}{l}\text { Study protocol for the 'HelpMeDoIt!' randomised controlled } \\
\text { feasibility trial: an app, web and social support-based weight } \\
\text { loss intervention for adults with obesity }\end{array}$ \\
\hline Samhan, B., et al. & $\begin{array}{l}\text { The Trajectory of IT in Healthcare at HICSS: A Literature } \\
\text { Review, Analysis, and Future Directions }\end{array}$ \\
\hline Helm, R., et al. & $\begin{array}{l}\text { The effects of a lack of social recognition on online } \\
\text { communication behavior }\end{array}$ \\
\hline Ibrahim, N. F., et al. & $\begin{array}{l}\text { Exploring the effect of user engagement in online brand } \\
\text { communities: Evidence from Twitter }\end{array}$ \\
\hline $\mathrm{Fu}, \mathrm{X}$. , et al. & $\begin{array}{l}\text { User segmentation for retention management in online social } \\
\text { games }\end{array}$ \\
\hline Tobon, S., et al. & Gamification and online consumer decisions: Is the game over? \\
\hline $\begin{array}{l}\text { Wilkinson, C. R., \& Angeli, A. } \\
\text { D. }\end{array}$ & $\begin{array}{l}\text { Applying user centred and participatory design approaches to } \\
\text { commercial product development }\end{array}$ \\
\hline $\mathrm{Xu}, \mathrm{F}$., et al. & $\begin{array}{l}\text { What affects the user stickiness of the mainstream media } \\
\text { websites in China? }\end{array}$ \\
\hline Calvaresi, D., et al. & $\begin{array}{l}\text { EREBOTS: Privacy-Compliant Agent-Based Platform for } \\
\text { Multi-Scenario Personalized Health-Assistant Chatbots } \\
\end{array}$ \\
\hline Gilal, F. G., et al. & $\begin{array}{l}\text { The role of organismic integration theory in marketing science: } \\
\text { A systematic review and research agenda }\end{array}$ \\
\hline Huang, Y. T., \& Su, S. F. & $\begin{array}{l}\text { Motives for Instagram Use and Topics of Interest among Young } \\
\text { Adults }\end{array}$ \\
\hline Franco, C., et al. & $\begin{array}{l}\text { A fuzzy and bipolar approach to preference modeling with } \\
\text { application to need and desire }\end{array}$ \\
\hline Celino, I., \& Calegari, G. R. & $\begin{array}{l}\text { Submitting surveys via a conversational interface: An } \\
\text { evaluation of user acceptance and approach effectiveness }\end{array}$ \\
\hline Eisingerich, A. B., et al. & $\begin{array}{l}\text { Hook vs. hope: How to enhance customer engagement through } \\
\text { gamification }\end{array}$ \\
\hline Athilingam, P., et al. & $\begin{array}{l}\text { A Mobile Health Intervention to Improve Self-Care in Patients } \\
\text { With Heart Failure: Pilot Randomized Control Trial }\end{array}$ \\
\hline Militello, L., et al. & $\begin{array}{l}\text { Delivering Perinatal Health Information via a Voice Interactive } \\
\text { App (SMILE): Mixed Methods Feasibility Study }\end{array}$ \\
\hline
\end{tabular}




\begin{tabular}{|c|c|}
\hline Chen, J., et al. & $\begin{array}{l}\text { The Most Popular Smartphone Apps for Weight Loss: A } \\
\text { Quality Assessment }\end{array}$ \\
\hline Choo, C. C., \& Burton, A. A. & $\begin{array}{l}\text { Mobile Phone Apps for Behavioral Interventions for At-Risk } \\
\text { Drinkers in Australia: Literature Review }\end{array}$ \\
\hline Dallinga, J., et al. & $\begin{array}{l}\text { Analysis of the Features Important for the Effectiveness of } \\
\text { Physical Activity-Related Apps for Recreational Sports: Expert } \\
\text { Panel Approach }\end{array}$ \\
\hline Hassandra, M., et al. & $\begin{array}{l}\text { An mHealth App for Supporting Quitters to Manage Cigarette } \\
\text { Cravings With Short Bouts of Physical Activity: A } \\
\text { Randomized Pilot Feasibility and Acceptability Study }\end{array}$ \\
\hline Hauser-Ulrich, S., et al. & $\begin{array}{l}\text { A Smartphone-Based Health Care Chatbot to Promote } \\
\text { Self-Management of Chronic Pain (SELMA): Pilot } \\
\text { Randomized Controlled Trial }\end{array}$ \\
\hline Hoeppner, B. B., et al. & $\begin{array}{l}\text { Leveraging Positive Psychology to Support Smoking Cessation } \\
\text { in Nondaily Smokers Using a Smartphone App: Feasibility and } \\
\text { Acceptability Study }\end{array}$ \\
\hline Thomas, J. G., \& Wing, R. R. & $\begin{array}{l}\text { Health-E-Call, a Smartphone-Assisted Behavioral Obesity } \\
\text { Treatment: Pilot Study }\end{array}$ \\
\hline Jongerius, C., et al. & $\begin{array}{l}\text { Research-Tested Mobile Apps for Breast Cancer Care: } \\
\text { Systematic Review }\end{array}$ \\
\hline Kim, B. Y., \& Lee, J. & $\begin{array}{l}\text { Smart Devices for Older Adults Managing Chronic Disease: A } \\
\text { Scoping Review }\end{array}$ \\
\hline Simons, D., et al. & $\begin{array}{l}\text { A Smartphone App to Promote an Active Lifestyle in } \\
\text { Lower-Educated Working Young Adults: Development, } \\
\text { Usability, Acceptability, and Feasibility Study }\end{array}$ \\
\hline Roosan, D., et al. & $\begin{array}{l}\text { Artificial Intelligence-Powered Smartphone App to Facilitate } \\
\text { Medication Adherence: Protocol for a Human Factors Design } \\
\text { Study }\end{array}$ \\
\hline Alalwan, A. A., et al. & $\begin{array}{l}\text { Examining the impact of mobile interactivity on customer } \\
\text { engagement in the context of mobile shopping }\end{array}$ \\
\hline Campbell, W., et al. & $\begin{array}{l}\text { Overcoming Addictions, a Web-Based Application, and } \\
\text { SMART Recovery, an Online and In-Person Mutual Help } \\
\text { Group for Problem Drinkers, Part 2: Six-Month Outcomes of a } \\
\text { Randomized Controlled Trial and Qualitative Feedback From } \\
\text { Participants }\end{array}$ \\
\hline Khoong, E. C., et al. & $\begin{array}{l}\text { The Use of Technology for Communicating With Clinicians or } \\
\text { Seeking Health Information in a Multilingual Urban Cohort: } \\
\text { Cross-Sectional Survey }\end{array}$ \\
\hline Yeung, D. & $\begin{array}{l}\text { Social Media as a Catalyst for Policy Action and Social Change } \\
\text { for Health and Well-Being: Viewpoint }\end{array}$ \\
\hline
\end{tabular}




\begin{tabular}{|l|l|}
\hline Pisani, A. R., et al. & $\begin{array}{l}\text { Human Subjects Protection and Technology in Prevention } \\
\text { Science: Selected Opportunities and Challenges }\end{array}$ \\
\hline Dong, Y., et al. & $\begin{array}{l}\text { A Scenario Interaction-centered Conceptual Information Model } \\
\text { for UX Design of User-oriented Product-service System }\end{array}$ \\
\hline Wellsandt, S., et al. & $\begin{array}{l}\text { Qualitative Comparison of Requirements Elicitation } \\
\text { Techniques that are Used to Collect Feedback Information } \\
\text { about Product Use }\end{array}$ \\
\hline Ribeiro, N., et al. & Happy: Cancer Prevention Using Smartphones \\
\hline Vos, S., et al. & $\begin{array}{l}\text { From Problem to Solution: Developing a Personalized } \\
\text { Smartphone Application for Recreational Runners following a } \\
\text { Three-step Design Approach }\end{array}$ \\
\hline Castellacci, F., \& Tveito, V. & $\begin{array}{l}\text { Internet use and well-being: A survey and a theoretical } \\
\text { framework }\end{array}$ \\
\hline Suh, A., \& Li, M. & $\begin{array}{l}\text { Digital Tracing during the COVID-19 Pandemic: User } \\
\text { Appraisal, Emotion, and Continuance Intention }\end{array}$ \\
\hline Murillo-Zegarra, M., et al. & $\begin{array}{l}\text { The Effects of Mobile Advertising Alerts and Perceived Value } \\
\text { on Continuance Intention for Branded Mobile Apps }\end{array}$ \\
\hline Youssef, A. B., et al. & Digitalization of the economy and entrepreneurship intention \\
\hline Liu, S., et al. & $\begin{array}{l}\text { Social support, belongingness, and value co-creation behaviors } \\
\text { in online health communities }\end{array}$ \\
\hline Zhang, X., et al. & $\begin{array}{l}\text { Exploring short-form video application addiction: } \\
\text { Socio-technical and attachment perspectives }\end{array}$ \\
\hline Manne, K. & How social media impacts consumer spending \\
\hline Columbia Business School. & Social networks may inflate self-esteem, reduce self-control \\
\hline Williams, A. & $\begin{array}{l}\text { Enhancing knowledge crucial to improving energy-saving } \\
\text { behaviors }\end{array}$ \\
\hline University of Pennsylvania & Annenberg School for \\
Communication. & Social networks can motivate people to exercise more \\
\hline Endert, T. V., \& Mohr, P. & $\begin{array}{l}\text { Smartphone screen time linked to preference for quicker but } \\
\text { smaller rewards }\end{array}$ \\
\hline Odgers, C. \& Robb, M. B. & $\begin{array}{l}\text { Tweens, Teens, Tech, and Mental Health: Coming of Age in an } \\
\text { Increasingly Digital, Uncertain, and Unequal World, 2020 }\end{array}$ \\
\hline Adam, D., \& Nicholson, T. & The Digital Journey \\
\hline
\end{tabular}

\section{Appendix 4}

\section{Study Characteristics}




\begin{tabular}{|c|c|c|c|c|c|}
\hline $\begin{array}{l}\text { Author. } \\
\text { Date. Title of } \\
\text { study }\end{array}$ & Country & $\begin{array}{l}\text { Study } \\
\text { design, } \\
\text { duration } \\
\text {, and } \\
\text { participa } \\
\text { nts }\end{array}$ & $\begin{array}{l}\text { Type of } \\
\text { data }\end{array}$ & $\begin{array}{l}\text { Identified social } \\
\text { trends/behaviour towards } \\
\text { apps - Outcome }\end{array}$ & Relevant \\
\hline $\begin{array}{l}\text { Graham, } \\
\text { A.K. et al. } \\
2020 . \\
\text { Implementati } \\
\text { on strategies } \\
\text { for digital } \\
\text { mental health } \\
\text { interventions } \\
\text { in health care } \\
\text { settings }\end{array}$ & USA & $\begin{array}{l}\text { Mixed-m } \\
\text { ethod }\end{array}$ & $\begin{array}{l}\text { Non-rando } \\
\text { mized } \\
\text { controlled } \\
\text { Trials } \\
\text { Subjective } \\
\text { phone } \\
\text { engagement } \\
\text { Smartphone } \\
\text { users }\end{array}$ & $\begin{array}{l}\text { Digital mental health } \\
\text { interventions (DMHIs) } \\
\text { have been found to be } \\
\text { effective and efficient } \\
\text { within healthcare if } \\
\text { implemented properly. } \\
\text { Various implementation } \\
\text { strategies and features are } \\
\text { suggested, including } \\
\text { navigation tools, user } \\
\text { interface simplicity, and } \\
\text { therapeutic consumer } \\
\text { suggestion. }\end{array}$ & Yes \\
\hline $\begin{array}{l}\text { Schueller, S. } \\
\text { M., \& } \\
\text { Torous, J. } \\
\text { 2020. Scaling } \\
\text { evidence-bas } \\
\text { ed treatments } \\
\text { through } \\
\text { digital mental } \\
\text { health. }\end{array}$ & USA & $\begin{array}{l}\text { Quantitat } \\
\text { ive }\end{array}$ & $\begin{array}{l}\text { Non-rando } \\
\text { mized } \\
\text { studies }\end{array}$ & $\begin{array}{l}\text { Digital mental health } \\
\text { implementation is denoted } \\
\text { to have a large amount of } \\
\text { unrealized potential. } 82 \% \\
\text { of America has a } \\
\text { smartphone. Evidence } \\
\text { based treatments have } \\
\text { potential if digital health } \\
\text { implementation strategies } \\
\text { have continuous } \\
\text { growth/research. It is } \\
\text { identified that if DHMI is } \\
\text { combined with } \\
\text { implementation science } \\
\text { there is greater potential } \\
\text { and a higher efficacy rate } \\
\text { for DHMIs. The } \\
\text { implementation nuances } \\
\text { and execution gauges the } \\
\text { quality of the mental health } \\
\text { service delivery including } \\
\text { device compatibility, } \\
\text { technological literacy, user } \\
\text { interface, etc. }\end{array}$ & Yes \\
\hline
\end{tabular}




\begin{tabular}{|c|c|c|c|c|c|}
\hline $\begin{array}{l}\text { McColl, L. } \\
\text { D., et al. } \\
\text { 2014. Peer } \\
\text { support } \\
\text { intervention } \\
\text { through } \\
\text { mobile } \\
\text { application: } \\
\text { An } \\
\text { integrative } \\
\text { literature } \\
\text { review and } \\
\text { future } \\
\text { directions }\end{array}$ & Canada & $\begin{array}{l}\text { Qualitati } \\
\text { ve: } 116 \\
\text { articles } \\
\text { were } \\
\text { found } \\
\text { through } \\
\text { searches } \\
\text { out of } \\
\text { which } 23 \\
\text { articles } \\
\text { were } \\
\text { included } \\
\text { and } \\
\text { reviewed. }\end{array}$ & $\begin{array}{l}\text { Integrative } \\
\text { Literature } \\
\text { Review }\end{array}$ & $\begin{array}{l}\text { There are positive outcomes } \\
\text { of technology based peer } \\
\text { support such as phone calls, } \\
\text { texting, and online groups. } \\
\text { Findings showed that peer } \\
\text { support based apps have } \\
\text { potential for decreasing } \\
\text { stress on individuals. The } \\
\text { combination of peer support } \\
\text { apps and face-to-face } \\
\text { interventions have potential } \\
\text { for more positive outcomes, } \\
\text { as compared to using only } \\
\text { one. However, results also } \\
\text { suggest that peer support } \\
\text { based apps are not } \\
\text { sufficient enough to replace } \\
\text { face-to-face interventions } \\
\text { and other direct } \\
\text { interventions. }\end{array}$ & Yes \\
\hline $\begin{array}{l}\text { Wood, A.E., } \\
\text { et al. } 2017 . \\
\text { Reduction of } \\
\text { Burnout in } \\
\text { Mental } \\
\text { Health Care } \\
\text { Providers } \\
\text { Using the } \\
\text { Provider } \\
\text { Resilience } \\
\text { Mobile } \\
\text { Application }\end{array}$ & USA & $\begin{array}{l}\text { Mixed-m } \\
\text { ethod. } 30 \\
\text { mental } \\
\text { health } \\
\text { care } \\
\text { professio } \\
\text { nals used } \\
\text { the } \\
\text { Provider } \\
\text { Resilienc } \\
\text { e app for } \\
\text { a month. }\end{array}$ & $\begin{array}{l}\text { Experiment } \\
\text { al study: } \\
\text { answered } \\
\text { questionnair } \\
\text { e based on } \\
\text { the System } \\
\text { Usability } \\
\text { Scale; } \\
\text { Provider } \\
\text { Resilience } \\
\text { Scale was } \\
\text { used for } \\
\text { measuring } \\
\text { acceptabilit } \\
\text { y of the app. } \\
\text { Professional } \\
\text { Quality of } \\
\text { Life-Revisio } \\
\text { n IV (a } \\
\text { 30-item } \\
\text { self-reportin } \\
\text { g measure) } \\
\text { was used to } \\
\text { measure the } \\
\text { effectivenes }\end{array}$ & $\begin{array}{l}\text { After the usage of the } \\
\text { Provider Resilience app for } \\
1 \text { month, participants } \\
\text { appeared to be } \\
\text { psychologically healthier, } \\
\text { had lower levels of burnout, } \\
\text { and average levels of } \\
\text { Compassion Satisfaction } \\
\text { and Compassion } \\
\text { Fatigue/Secondary Trauma. } \\
\text { The app was given a } 79.7 \\
\text { score for usability on the } \\
\text { System Usability Scale. } \\
\text { The Professional Quality of } \\
\text { Life Scale showed } \\
\text { significant decreases on the } \\
\text { Burnout and Compassion } \\
\text { Fatigue subscales. Initial } \\
\text { data for the Provider } \\
\text { Resilience app suggests } \\
\text { efficacy of digital tools in } \\
\text { reducing burnout and } \\
\text { compassion fatigue. }\end{array}$ & Yes \\
\hline
\end{tabular}




\begin{tabular}{|c|c|c|c|c|c|}
\hline & & & $\begin{array}{l}\text { s of the app. } \\
\text { There were } \\
\text { three } \\
\text { subscales in } \\
\text { this tool: } \\
\text { Burnout, } \\
\text { Compassion } \\
\text { Fatigue/Sec } \\
\text { ondary } \\
\text { Trauma, and } \\
\text { Compassion } \\
\text { Satisfaction. }\end{array}$ & & \\
\hline $\begin{array}{l}\text { Kolenik, T., } \\
\text { \& Matjaž, G. } \\
2021 . \\
\text { Intelligent } \\
\text { Cognitive } \\
\text { Assistants for } \\
\text { Attitude and } \\
\text { Behavior } \\
\text { Change } \\
\text { Support in } \\
\text { Mental } \\
\text { Health: } \\
\text { State-of-the- } \\
\text { Art Technical } \\
\text { Review }\end{array}$ & Slovenia & $\begin{array}{l}\text { Qualitati } \\
\text { ve: } 10 \\
\text { papers } \\
\text { reviewed }\end{array}$ & $\begin{array}{l}\text { State-of-the- } \\
\text { Art } \\
\text { Technical } \\
\text { Review of } \\
\text { Intelligent } \\
\text { Cognitive } \\
\text { assistant } \\
\text { (ICA) } \\
\text { technology } \\
\text { used for } \\
\text { attitude and } \\
\text { behaviour } \\
\text { change for } \\
\text { people with } \\
\text { stress, } \\
\text { anxiety and } \\
\text { depression } \\
\text { (SAD). }\end{array}$ & $\begin{array}{l}\text { The most successful } \\
\text { systems of approach for } \\
\text { eliciting attitude and } \\
\text { behaviour change in users } \\
\text { expressing SAD are: } \\
\text { Comprehensive user } \\
\text { models, classification-based } \\
\text { assessment, personalized } \\
\text { intervention, and dialogue } \\
\text { tree conversational models. }\end{array}$ & Yes \\
\hline $\begin{array}{l}\text { Hsiao, M. H. } \\
\text { 2018. A } \\
\text { conceptual } \\
\text { framework } \\
\text { for } \\
\text { technology-e } \\
\text { nabled and } \\
\text { technology-d } \\
\text { ependent user } \\
\text { behavior } \\
\text { toward } \\
\text { device mesh } \\
\text { and mesh app }\end{array}$ & Taiwan & $\begin{array}{l}\text { Qualitati } \\
\text { ve }\end{array}$ & $\begin{array}{l}\text { Literature } \\
\text { review } \\
\text { Conceptual } \\
\text { framework } \\
\text { to } \\
\text { understand } \\
\text { the use of of } \\
\text { the mesh } \\
\text { device and } \\
\text { app }\end{array}$ & $\begin{array}{l}\text { Mesh apps are able to } \\
\text { predict people's needs by } \\
\text { gathering contextual data } \\
\text { on personal daily patterns. } \\
\text { The app is then able to } \\
\text { provide info or services } \\
\text { across devices. The use of } \\
\text { such apps is affected by the } \\
\text { motivation levels of such } \\
\text { users and not only the } \\
\text { technology. }\end{array}$ & No \\
\hline
\end{tabular}




\begin{tabular}{|c|c|c|c|c|c|}
\hline $\begin{array}{l}\text { Alqahtani, R., } \\
\& \text { Orji, F. } \\
2020 . \\
\text { Insights from } \\
\text { user reviews } \\
\text { to improve } \\
\text { mental health } \\
\text { apps }\end{array}$ & Canada & $\begin{array}{l}\text { Qualitati } \\
\text { ve: } 106 \\
\text { mental } \\
\text { health } \\
\text { apps } \\
\text { from App } \\
\text { store and } \\
\text { google } \\
\text { play were } \\
\text { considere } \\
\text { d. } 13549 \\
\text { reviews } \\
\text { were } \\
\text { analyzed. }\end{array}$ & $\begin{array}{l}\text { Literature } \\
\text { review of } \\
\text { user reviews } \\
\text { of mobile } \\
\text { apps for } \\
\text { mental } \\
\text { health } \\
\text { issues }\end{array}$ & $\begin{array}{l}\text { Users preferred apps with } \\
\text { more user interface and } \\
\text { friendliness, and a variety } \\
\text { of options, functionalities } \\
\text { and content to choose from. } \\
\text { Poor usability was the most } \\
\text { prominent cause for } \\
\text { preventing usage of mental } \\
\text { health apps. Lack of content } \\
\text { variety, personalization, } \\
\text { customer service, trust, } \\
\text { security and privacy issues } \\
\text { were other reasons for lack } \\
\text { of usage. Future technology } \\
\text { may offer the potential to } \\
\text { predict the mental health } \\
\text { needs of users ahead of } \\
\text { time. }\end{array}$ & Yes \\
\hline $\begin{array}{l}\text { White, B. K., } \\
\text { et al. } 2016 . \\
\text { Designing } \\
\text { evaluation } \\
\text { plans for } \\
\text { health } \\
\text { promotion } \\
\text { mHealth } \\
\text { interventions: } \\
\text { a case study } \\
\text { of the Milk } \\
\text { Man mobile } \\
\text { man }\end{array}$ & Australia & $\begin{array}{l}\text { Qualitati } \\
\text { ve }\end{array}$ & $\begin{array}{l}\text { Case Study; } \\
\text { Randomized } \\
\text { Control } \\
\text { Trial }\end{array}$ & $\begin{array}{l}\text { Challenges for mHealth } \\
\text { interventions include } \\
\text { privacy and data security; } \\
\text { more evidence for the } \\
\text { effectiveness of the } \\
\text { intervention and } \\
\text { sustainability of the } \\
\text { intervention beyond funded } \\
\text { projects. The incorporation } \\
\text { of a comprehensive analysis } \\
\text { of such interventions will } \\
\text { allow for a greater } \\
\text { understanding of how } \\
\text { mHealth can be best used. } \\
\text { Evaluation plans are needed } \\
\text { to help guide health } \\
\text { promotion practitioners } \\
\text { working in mHealth to } \\
\text { ensure effectiveness of } \\
\text { apps. }\end{array}$ & Yes \\
\hline $\begin{array}{l}\text { Naar, S., et } \\
\text { al. } 2018 . \\
\text { Innovative } \\
\text { study designs } \\
\text { and methods } \\
\text { for }\end{array}$ & USA & $\begin{array}{l}\text { Qualitati } \\
\text { ve, } \\
\text { methods } \\
\text { used at } \\
\text { 2-day } \\
\text { health }\end{array}$ & $\begin{array}{l}\text { Literature } \\
\text { review } \\
\text { The paper is } \\
\text { based on a } \\
\text { workshop. }\end{array}$ & $\begin{array}{l}\text { New and more effective } \\
\text { approaches to drive } \\
\text { behavioural change needs } \\
\text { to be developed and tested } \\
\text { in real-world settings. } \\
\text { Currently effective and }\end{array}$ & Yes \\
\hline
\end{tabular}




\begin{tabular}{|c|c|c|c|c|c|}
\hline $\begin{array}{l}\text { optimizing } \\
\text { and } \\
\text { implementing } \\
\text { behavioral } \\
\text { interventions } \\
\text { to improve } \\
\text { health }\end{array}$ & & $\begin{array}{l}\text { worksho } \\
\text { p }\end{array}$ & & $\begin{array}{l}\text { proven interventions need } \\
\text { to be more widely } \\
\text { implemented in clinical } \\
\text { practice and community. } \\
\text { The use of hybrid designs } \\
\text { for trials can reduce the } \\
\text { science-practice gap. } \\
\text { Integrating clinical trials in } \\
\text { real-world settings can help } \\
\text { decrease this gap. There are } \\
\text { three types of hybrids that } \\
\text { have varying priorities; } \\
\text { Type } 1 \text { hybrid prioritizes } \\
\text { effectiveness primarily and } \\
\text { implementation } \\
\text { secondarily; Type } 2 \text { hybrid } \\
\text { prioritizes effectiveness and } \\
\text { implementation equally; } \\
\text { Type } 3 \text { hybridization } \\
\text { prioritizes implementation } \\
\text { primarily and effectiveness } \\
\text { secondarily. }\end{array}$ & \\
\hline $\begin{array}{l}\text { Wright, C. J. } \\
\text { C, et al. } 2019 . \\
\text { Barriers and } \\
\text { opportunities } \\
\text { in the } \\
\text { translation of } \\
\text { mobile phone } \\
\text { and social } \\
\text { media } \\
\text { interventions } \\
\text { between } \\
\text { research and } \\
\text { health } \\
\text { promotion } \\
\text { practice in } \\
\text { Australia: a } \\
\text { qualitative } \\
\text { study of } \\
\text { expert } \\
\text { perspectives }\end{array}$ & Australia & $\begin{array}{l}\text { Qualitati } \\
\text { ve: } 9 \\
\text { technolo } \\
\text { gy based } \\
\text { experts } \\
\text { and } 9 \\
\text { health } \\
\text { promotio } \\
\text { n experts }\end{array}$ & $\begin{array}{l}\text { Observation } \\
\text { al study: } \\
\text { interviews } \\
\text { with } \\
\text { experienced } \\
\text { researchers } \\
\text { in } \\
\text { technology } \\
\text { based } \\
\text { intervention } \\
\text { s and health } \\
\text { promotion } \\
\text { experts }\end{array}$ & $\begin{array}{l}\text { For technology-based } \\
\text { prevention interventions to } \\
\text { succeed, it is vital that } \\
\text { translation is prioritized by } \\
\text { both researchers and } \\
\text { practitioners. } \\
\text { Competing priorities, } \\
\text { resource limitation and } \\
\text { organisational capacity are } \\
\text { important for the use of } \\
\text { evidence in program } \\
\text { planning, engagement in } \\
\text { translation and evaluation } \\
\text { practice. }\end{array}$ & Yes \\
\hline $\begin{array}{l}\text { Li, M., et al. } \\
\text { 2017. Expert }\end{array}$ & China & $\begin{array}{l}\text { Qualitati } \\
\text { ve: } 120\end{array}$ & $\begin{array}{l}\text { Experiment } \\
\text { al Study }\end{array}$ & $\begin{array}{l}\text { The virtual advisor identity } \\
\text { influences the cognitive and }\end{array}$ & Yes \\
\hline
\end{tabular}




\begin{tabular}{|c|c|c|c|c|c|}
\hline $\begin{array}{l}\text { or peer? } \\
\text { Understandin } \\
\mathrm{g} \text { the } \\
\text { implications } \\
\text { of virtual } \\
\text { advisor } \\
\text { identity on } \\
\text { emergency } \\
\text { rescuer } \\
\text { empowermen } \\
\text { t in mobile } \\
\text { psychological } \\
\text { self-help } \\
\text { services }\end{array}$ & & $\begin{array}{l}\text { emergenc } \\
\text { y } \\
\text { rescuers; } \\
\text { A tool } \\
\text { develope } \\
\text { d to help } \\
\text { emergenc } \\
\text { y } \\
\text { rescuers } \\
\text { through } \\
\text { using a } \\
\text { mobile } \\
\text { psycholo } \\
\text { gical } \\
\text { self-help } \\
\text { tool. }\end{array}$ & $\begin{array}{l}\text { with three } \\
\text { phases: } \\
\text { watching a } \\
\text { video } \\
\text { describing } \\
\text { the virtual } \\
\text { ERMS, } \\
\text { demonstrati } \\
\text { ng rescuers } \\
\text { how to use } \\
\text { virtual } \\
\text { advisory } \\
\text { system, and } \\
\text { completing } \\
\text { a } \\
\text { questionnair } \\
\text { e }\end{array}$ & $\begin{array}{l}\text { emotional state of the } \\
\text { rescuer through } \\
\text { empowering them. It does } \\
\text { this through providing them } \\
\text { with a stronger sense of } \\
\text { social presence and a better } \\
\text { feeling of inner resonance. }\end{array}$ & \\
\hline $\begin{array}{l}\text { Mirzaei, T., } \\
\& \\
\text { Esmaeilzadeh } \\
\text {, P. } 2021 . \\
\text { Engagement } \\
\text { in online } \\
\text { health } \\
\text { communities: } \\
\text { Channel } \\
\text { expansion } \\
\text { and social } \\
\text { exchanges }\end{array}$ & USA & $\begin{array}{l}\text { Qualitati } \\
\text { ve; } \\
\text { survey } \\
\text { data from } \\
348 \\
\text { participa } \\
\text { nts }\end{array}$ & $\begin{array}{l}\text { Observation } \\
\text { al study: } \\
\text { survey data } \\
\text { analysis } \\
\text { perceived } \\
\text { channel } \\
\text { richness, } \\
\text { social } \\
\text { support, and } \\
\text { willingness } \\
\text { to exchange } \\
\text { information } \\
\text { on online } \\
\text { health } \\
\text { communitie } \\
\text { s (OHC). }\end{array}$ & $\begin{array}{l}\text { Perceived channel richness } \\
\text { positively influences OHC } \\
\text { engagement. This is due to } \\
\text { the positive effects of OHC } \\
\text { on the expectation of } \\
\text { information support and the } \\
\text { expectation of emotional } \\
\text { support. Patient willingness } \\
\text { to share and seek } \\
\text { information is affected by } \\
\text { health status. Engagement } \\
\text { in OHCs enhances self-care } \\
\text { efficacy and perceived } \\
\text { health outcomes. } \\
\text { Social support may increase } \\
\text { members' engagement and } \\
\text { information exchange in } \\
\text { OHCs. Administrators of } \\
\text { OHCs need to improve the } \\
\text { usefulness and credibility of } \\
\text { the health information } \\
\text { exchange and highlight } \\
\text { emotional and } \\
\text { informational support from } \\
\text { others. }\end{array}$ & Yes \\
\hline $\begin{array}{l}\text { Dini, G., et } \\
\text { al. } 2014 \text {. }\end{array}$ & Italy & $\begin{array}{l}\text { Qualitati } \\
\text { ve }\end{array}$ & $\begin{array}{l}\text { Literature } \\
\text { Review }\end{array}$ & $\begin{array}{l}\text { Findings show that the pure } \\
\mathrm{Q} \& \mathrm{~A} \text { interface is the most }\end{array}$ & No \\
\hline
\end{tabular}




\begin{tabular}{|c|c|c|c|c|c|}
\hline $\begin{array}{l}\text { Social and } \\
\text { Q\&A } \\
\text { interfaces for } \\
\text { app } \\
\text { download }\end{array}$ & & & & $\begin{array}{l}\text { effective in minimizing } \\
\text { users' incoherent } \\
\text { behaviours and the } \\
\text { difference in reputation } \\
\text { rankings significantly } \\
\text { influence users. }\end{array}$ & \\
\hline $\begin{array}{l}\text { Bauer, M., et } \\
\text { al. } 2020 . \\
\text { Smartphones } \\
\text { in mental } \\
\text { health: a } \\
\text { critical } \\
\text { review of } \\
\text { background } \\
\text { issues, } \\
\text { current status } \\
\text { and future } \\
\text { concerns }\end{array}$ & Germany & $\begin{array}{l}\text { Qualitati } \\
\text { ve }\end{array}$ & $\begin{array}{l}\text { Literature } \\
\text { Review }\end{array}$ & $\begin{array}{l}\text { Psychiatry based } \\
\text { technology should focus on } \\
\text { automating functions that } \\
\text { will provide patients with a } \\
\text { variety of methods to } \\
\text { access and use the } \\
\text { technology to best fit the } \\
\text { patients' lifestyles and } \\
\text { budget. Patients prefer } \\
\text { different types of consumer } \\
\text { technologies. }\end{array}$ & Yes \\
\hline $\begin{array}{l}\text { Hwang, W. } \\
\text { J., et al. } 2020 . \\
\text { Research } \\
\text { Trends on } \\
\text { Mobile } \\
\text { Mental } \\
\text { Health } \\
\text { Application } \\
\text { for General } \\
\text { Population: A } \\
\text { Scoping } \\
\text { Review }\end{array}$ & Korea & $\begin{array}{l}\text { Quantitat } \\
\text { ive; } 14 \\
\text { studies } \\
\text { analyzed; } \\
13 \\
\text { experime } \\
\text { ntal with } \\
71.4 \% \\
\text { randomiz } \\
\text { ed } \\
\text { control } \\
\text { trials. }\end{array}$ & $\begin{array}{l}\text { Systematic } \\
\text { scoping } \\
\text { review; the } \\
\text { effects and } \\
\text { results of } \\
\text { mental } \\
\text { health } \\
\text { mobile apps } \\
\text { for the } \\
\text { general } \\
\text { adult } \\
\text { population } \\
\text { were } \\
\text { examined }\end{array}$ & $\begin{array}{l}\text { Stress, anxiety and } \\
\text { depression decreased when } \\
\text { using mental health apps. } \\
\text { Apps based on theoretical } \\
\text { knowledge and } \\
\text { well-designed research are } \\
\text { lacking. Most developed } \\
\text { apps for mental health are } \\
\text { designed to target subjects } \\
\text { who already have mental } \\
\text { health problems or to } \\
\text { support clinical treatments. } \\
\text { There is a lack of research } \\
\text { on the lasting effects of } \\
\text { mobile app interventions. } \\
\text { The rate of prolonged use } \\
\text { of mHealth apps was low, } \\
\text { ranging from two weeks to } \\
\text { six months. The } \\
\text { development of mHealth } \\
\text { apps was driven by } \\
\text { commercial and economic } \\
\text { motives rather than } \\
\text { scientific ones. }\end{array}$ & Yes \\
\hline Birkmeyer, & Germany & Qualitati & Observation & The user's general attitude & Yes \\
\hline
\end{tabular}




\begin{tabular}{|c|c|c|c|c|c|}
\hline $\begin{array}{l}\text { S., et al. } \\
2021 . \\
\text { Determinants } \\
\text { of mHealth } \\
\text { success: An } \\
\text { empirical } \\
\text { investigation } \\
\text { of the user } \\
\text { perspective }\end{array}$ & & $\begin{array}{l}\text { ve; } \\
\text { survey } \\
\text { data from } \\
263 \text { users } \\
\text { from an } \\
\text { internet } \\
\text { forum } \\
\text { were } \\
\text { collected }\end{array}$ & $\begin{array}{l}\text { Study: } \\
\text { Users of the } \\
\text { mHealth } \\
\text { app, } \\
\text { MyFitnessP } \\
\text { al, were } \\
\text { surveyed }\end{array}$ & $\begin{array}{l}\text { towards mHealth overall } \\
\text { affects the success of the } \\
\text { app. The user satisfaction, } \\
\text { which is driven by the } \\
\text { design of the app also } \\
\text { impacts the success. Social } \\
\text { networking has a moderate } \\
\text { effect on user satisfaction. } \\
\text { Overall user satisfaction has } \\
\text { a strong positive influence } \\
\text { on the continuous usage of } \\
\text { mHealth apps. }\end{array}$ & \\
\hline $\begin{array}{l}\text { Li, M., et al. } \\
2021 . \\
\text { Meaningful } \\
\text { gamification } \\
\text { for } \\
\text { psychological } \\
\text { empowermen } \\
\text { t: exploring } \\
\text { user affective } \\
\text { experience } \\
\text { mirroring in a } \\
\text { psychological } \\
\text { self-help } \\
\text { system }\end{array}$ & China & $\begin{array}{l}\text { Mixed-m } \\
\text { ethod; } 27 \\
\text { participa } \\
\text { nts }\end{array}$ & $\begin{array}{l}\text { Semi-struct } \\
\text { ured } \\
\text { interviews, } \\
\text { experience } \\
\text { sampling } \\
\text { experiment } \\
\text { and user bio } \\
\text { data } \\
\text { triangulatio } \\
\text { ns }\end{array}$ & $\begin{array}{l}\text { Users preferred a gamified } \\
\text { psychological self-help } \\
\text { system that could echo the } \\
\text { user's facial expressions in } \\
\text { real time. They were } \\
\text { perceived as more } \\
\text { trustworthy, empathetic and } \\
\text { capable of providing better } \\
\text { advice. The use of a visual } \\
\text { impact metaphor-based } \\
\text { (VIM) system was } \\
\text { considered more } \\
\text { empowering, allowing users } \\
\text { to gain more control over } \\
\text { their emotional well-being. } \\
\text { The system improved stress } \\
\text { and increased perceived } \\
\text { level of happiness. }\end{array}$ & Yes \\
\hline $\begin{array}{l}\text { Grace-Farfagl } \\
\text { ia, P. } 2019 . \\
\text { Social } \\
\text { Cognitive } \\
\text { Theories and } \\
\text { Electronic } \\
\text { Health } \\
\text { Design: } \\
\text { Scoping } \\
\text { Review }\end{array}$ & USA & $\begin{array}{l}\text { Qualitati } \\
\text { ve: } 161 \\
\text { web-base } \\
\text { d } \\
\text { interventi } \\
\text { ons } \\
\text { reviewed } \\
\text { from } \\
\text { January } \\
2006 \text { to } \\
\text { April } \\
2016 .\end{array}$ & $\begin{array}{l}\text { Systematic } \\
\text { scoping } \\
\text { review: } \\
\text { studies were } \\
\text { analyzed for } \\
\text { quality and } \\
\text { coded for } \\
\text { type of } \\
\text { social } \\
\text { design }\end{array}$ & $\begin{array}{l}\text { "Less than half of the } \\
\text { studies looked at social } \\
\text { support and motivational } \\
\text { needs }(43.8 \%) \text {, with most } \\
\text { relying on the internet for } \\
\text { the delivery of tailored } \\
\text { content for individual } \\
\text { participants. Many studies } \\
\text { did not recommend } \\
\text { expressive interaction tools, } \\
\text { like goal setting or } \\
\text { user-centred design." } \\
48.6 \% \text { of studies reviewed }\end{array}$ & Yes \\
\hline
\end{tabular}




\begin{tabular}{|c|c|c|c|c|c|}
\hline & & & & $\begin{array}{l}\text { had expressive interaction } \\
\text { tools which were } \\
\text { categorized as a strong tool. } \\
43.8 \% \text { of studies addressed } \\
\text { participant social support } \\
\text { and motivational needs. } \\
100 \% \text { of studies relied on } \\
\text { the web for providing } \\
\text { informational aid. } 75.9 \% \text { of } \\
\text { the studies tailored content } \\
\text { for the individual } \\
\text { participant. }\end{array}$ & \\
\hline $\begin{array}{l}\text { Stiles-Shields } \\
\text {, C., et al. } \\
2017 . \\
\text { Exploring } \\
\text { User } \\
\text { Learnability } \\
\text { and Learning } \\
\text { Performance } \\
\text { in an App for } \\
\text { Depression: } \\
\text { Usability } \\
\text { Stud }\end{array}$ & USA & $\begin{array}{l}\text { Mixed-m } \\
\text { ethod; } 20 \\
\text { participa } \\
\text { nts }\end{array}$ & $\begin{array}{l}\text { Experiment } \\
\text { al data: } 20 \\
\text { participants } \\
\text { did an in-lab } \\
\text { usability } \\
\text { testing of } \\
\text { the Thought } \\
\text { Challenger } \\
\text { app, which } \\
\text { is a } \\
\text { skill-buildin } \\
\text { g app that is } \\
\text { an } \\
\text { intervention } \\
\text { in cognitive } \\
\text { therapy. } \\
\text { Learnability } \\
\text { and } \\
\text { performance } \\
\text { was } \\
\text { measured. } \\
\text { Comparison } \\
\text { was drawn } \\
\text { between } \\
\text { individuals } \\
\text { with no or } \\
\text { mild } \\
\text { depression } \\
\text { with those } \\
\text { with } \\
\text { moderate to } \\
\text { severe } \\
\text { depression. }\end{array}$ & $\begin{array}{l}\text { The app elicited thought } \\
\text { record entries that met the } \\
\text { standard of accurately } \\
\text { reflecting Cognitive } \\
\text { Therapy thought records. } \\
75 \% \text { of the entries met this } \\
\text { standard. The app was } \\
\text { further able to impact } \\
\text { learning without requiring } \\
\text { users to read or engage with } \\
\text { didactic content. CT } \\
\text { knowledge and skills } \\
\text { improved after Thought } \\
\text { Challenger usage (P=.009). } \\
\text { Thus, Thought Challenger } \\
\text { was successful in helping } \\
\text { users with cognitive } \\
\text { restructuring. This } \\
\text { reasoning can be } \\
\text { generalized to all apps, } \\
\text { proving that apps can } \\
\text { provide users with the } \\
\text { ability to learn intervention } \\
\text { skills. }\end{array}$ & Yes \\
\hline
\end{tabular}




\begin{tabular}{|c|c|c|c|c|c|}
\hline $\begin{array}{l}\text { Bruehlman-S } \\
\text { enecal, E., et } \\
\text { al. } 2020 \text {. } \\
\text { Smartphone } \\
\text { App to } \\
\text { Address } \\
\text { Loneliness } \\
\text { Among } \\
\text { College } \\
\text { Students: } \\
\text { Pilot } \\
\text { Randomized } \\
\text { Controlled } \\
\text { Trial }\end{array}$ & USA & $\begin{array}{l}\text { Mixed } \\
\text { Method; } \\
221 \\
\text { first-year } \\
\text { college } \\
\text { student }\end{array}$ & $\begin{array}{l}\text { Randomized } \\
\text { control } \\
\text { study; } \\
\text { Intention-to- } \\
\text { treat } \\
\text { analyses } \\
\text { were used to } \\
\text { compare } \\
\text { self-assesse } \\
\text { d loneliness, } \\
\text { depressive } \\
\text { symptoms, } \\
\text { and other } \\
\text { mental } \\
\text { health } \\
\text { issues at } \\
\text { week } 0 \text { and } \\
\text { then week } \\
4 .\end{array}$ & $\begin{array}{l}\text { There were no significant } \\
\text { effects of the application on } \\
\text { participants' levels of } \\
\text { loneliness, mental health } \\
\text { issues or college adjustment } \\
\text { difficulties. The app had a } \\
\text { significant effect on } \\
\text { students with an elevated } \\
\text { risk for loneliness and } \\
\text { depression by preventing } \\
\text { them from experiencing } \\
\text { mid-semester depressive } \\
\text { symptoms and loneliness. It } \\
\text { also protected against poor } \\
\text { sleep quality, reduced social } \\
\text { support and reduced } \\
\text { belonging on campus. } \\
\text { Students with no elevated } \\
\text { risk of depression or } \\
\text { loneliness did not elicit } \\
\text { significant benefits from the } \\
\text { Nod app. However, there is } \\
\text { still some initial evidence } \\
\text { of the app's benefit for } \\
\text { vulnerable students. }\end{array}$ & Yes \\
\hline $\begin{array}{l}\text { Bucci, S., et } \\
\text { al. } 2018 . \\
\text { Early } \\
\text { Psychosis } \\
\text { Service User } \\
\text { Views on } \\
\text { Digital } \\
\text { Technology: } \\
\text { Qualitative } \\
\text { Analysis }\end{array}$ & $\begin{array}{l}\text { United } \\
\text { Kingdom }\end{array}$ & $\begin{array}{l}\text { Qualitati } \\
\text { ve: } 21 \\
\text { semi-stru } \\
\text { ctured } \\
\text { interview } \\
\text { s with } \\
\text { individua } \\
\text { ls who } \\
\text { registere } \\
\text { d for } \\
\text { early } \\
\text { interventi } \\
\text { on for } \\
\text { psychosis } \\
\text { services. }\end{array}$ & $\begin{array}{l}\text { Framework } \\
\text { analysis was } \\
\text { done with } \\
\text { collected } \\
\text { data. Things } \\
\text { that were } \\
\text { analyzed } \\
\text { included: } \\
\text { acceptabilit } \\
\text { y of } \\
\text { technology } \\
\text { for treating } \\
\text { psychosis } \\
\text { and mental } \\
\text { health } \\
\text { issues, } \\
\text { increasing } \\
\text { access to } \\
\text { mental } \\
\text { health }\end{array}$ & $\begin{array}{l}\text { The users' were mostly } \\
\text { positive about the use of } \\
\text { DHIs, and believed it was a } \\
\text { progressive and modern } \\
\text { platform to help with } \\
\text { mental support. Some users } \\
\text { were concerned about } \\
\text { having privacy and data } \\
\text { security being breached, so } \\
\text { those are areas that can } \\
\text { continue to be developed. } \\
\text { Findings show that DHIs } \\
\text { were perceived as } \\
\text { destigmatizing, overcoming } \\
\text { barriers of traditional } \\
\text { interventions, facilitating } \\
\text { communication and } \\
\text { empowering to users. }\end{array}$ & Yes \\
\hline
\end{tabular}




\begin{tabular}{|c|c|c|c|c|c|}
\hline & & & $\begin{array}{l}\text { support } \\
\text { using } \\
\text { technology, } \\
\text { barriers to } \\
\text { adopting } \\
\text { digital } \\
\text { health } \\
\text { intervention } \\
\text { s (DHI), and } \\
\text { safety and } \\
\text { security } \\
\text { concerns. } \\
\text { The } \\
\text { blending of } \\
\text { digital } \\
\text { health } \\
\text { intervention } \\
\text { s with } \\
\text { face-to-face } \\
\text { intervention } \\
\text { s and } \\
\text { empowerme } \\
\text { nt through } \\
\text { these } \\
\text { mediums } \\
\text { were also } \\
\text { considered. }\end{array}$ & & \\
\hline $\begin{array}{l}\text { Wesselman, } \\
\text { L. M., et al. } \\
2019 \text {. } \\
\text { Web-Based } \\
\text { Multidomain } \\
\text { Lifestyle } \\
\text { Programs for } \\
\text { Brain Health: } \\
\text { Comprehensi } \\
\text { ve Overview } \\
\text { and } \\
\text { Meta-Analysi } \\
\text { s }\end{array}$ & $\begin{array}{l}\text { Netherla } \\
\text { nds }\end{array}$ & $\begin{array}{l}\text { Mixed-m } \\
\text { ethod, } \\
\text { meta-ana } \\
\text { lysis of } \\
\text { studies } \\
\text { describin } \\
\text { g } \\
\text { Web-base } \\
\text { d } \\
\text { lifestyle } \\
\text { programs }\end{array}$ & $\begin{array}{l}\text { Meta-analys } \\
\text { is of studies } \\
\text { describing } \\
\text { Web-based } \\
\text { lifestyle } \\
\text { programs } \\
\text { User } \\
\text { evaluations } \\
\text { Program } \\
\text { characteristi } \\
\text { cs (target } \\
\text { population, } \\
\text { duration, } \\
\text { frequency, } \\
\text { tailoring, } \\
\text { platform, } \\
\text { availability) } \\
\text { Results of }\end{array}$ & $\begin{array}{l}\text { There were } 14 \text { Web-based } \\
\text { multidomain lifestyle } \\
\text { programs discovered that } \\
\text { were focused on optimizing } \\
\text { brain health. Even though } \\
\text { the programs were } \\
\text { heterogeneous in nature, } \\
\text { they all were able to } \\
\text { positively influence brain } \\
\text { health outcomes and were } \\
\text { able to contribute to the } \\
\text { prevention of dementia. }\end{array}$ & Yes \\
\hline
\end{tabular}




\begin{tabular}{|c|c|c|c|c|c|}
\hline & & & $\begin{array}{l}\text { program } \\
\text { evaluations } \\
\text { (effectivene } \\
\text { ss, user } \\
\text { evaluations, } \\
\text { and } \\
\text { adherence) }\end{array}$ & & \\
\hline $\begin{array}{l}\text { Lo, B., et al. } \\
2020 . \\
\text { Surveying the } \\
\text { role of } \\
\text { analytics in } \\
\text { evaluating } \\
\text { digital mental } \\
\text { health } \\
\text { interventions } \\
\text { for } \\
\text { transition-age } \\
\text { d youth: } \\
\text { Scoping } \\
\text { review }\end{array}$ & Canada & $\begin{array}{l}\text { Mixed-m } \\
\text { ethod: } \\
\text { review of } \\
\text { current } \\
\text { literature } \\
\text { regarding } \\
\text { digital } \\
\text { mental } \\
\text { health } \\
\text { innovatio } \\
\text { ns }\end{array}$ & $\begin{array}{l}\text { Systemic } \\
\text { Review }\end{array}$ & $\begin{array}{l}\text { There was variability and } \\
\text { heterogeneity helps to } \\
\text { evaluate digital mental } \\
\text { health interventions for } \\
\text { youth. There is an } \\
\text { increasing trend of user } \\
\text { analytics being added into } \\
\text { the apps. There are still } \\
\text { existing gaps related to } \\
\text { selecting metrics to } \\
\text { measure user engagement, } \\
\text { which will be investigated } \\
\text { in future studies. Current } \\
\text { papers that look at analytics } \\
\text { for mHealth apps are not } \\
\text { looking at the adoption of } \\
\text { technology into } \\
\text { interventions. Real world } \\
\text { engagement with mHealth } \\
\text { apps is relatively low and } \\
\text { thus understanding } \\
\text { adoption will help with this. }\end{array}$ & $\begin{array}{l}\text { No - } \\
\text { results } \\
\text { are not } \\
\text { useful in } \\
\text { understan } \\
\text { ding } \\
\text { social } \\
\text { perceptio } \\
\text { ns of the } \\
\text { app }\end{array}$ \\
\hline $\begin{array}{l}\text { Parsons, C. } \\
\text { E., et al. } \\
2020 . \\
\text { Smartphone } \\
\text { Monitoring } \\
\text { of } \\
\text { Participants, } \\
\text { Engagement } \\
\text { With Home } \\
\text { Practice } \\
\text { During } \\
\text { Mindfulness- } \\
\text { Based Stress } \\
\text { Reduction: } \\
\text { Observational }\end{array}$ & Denmark & $\begin{array}{l}\text { Mixed-m } \\
\text { ethod, } 25 \\
\text { participa } \\
\text { nts used } \\
\text { a new } \\
\text { smartpho } \\
\text { ne app } \\
\text { designed } \\
\text { to present } \\
\text { participa } \\
\text { nts with } \\
\text { home } \\
\text { practice } \\
\text { guides } \\
\text { (e.g. }\end{array}$ & $\begin{array}{l}\text { Observation } \\
\text { al Study }\end{array}$ & $\begin{array}{l}\text { Participants listened to a } \\
\text { median of } 3 \text { of the } 6 \text { total } \\
\text { practice sessions and didn't } \\
\text { have a routine or regular } \\
\text { time. They would practice } \\
\text { most frequently in the } \\
\text { morning, whereas the peak } \\
\text { practice time was in the } \\
\text { evening for weekends. In } \\
\text { the future, it is feasible to } \\
\text { integrate a monitoring } \\
\text { approach into mindfulness } \\
\text { interventions in order to } \\
\text { provide user insights. }\end{array}$ & Yes \\
\hline
\end{tabular}




\begin{tabular}{|c|c|c|c|c|c|}
\hline Study & & $\begin{array}{l}\text { body } \\
\text { scan, } \\
\text { seated } \\
\text { meditatio } \\
\mathrm{n}, \text { and } \\
\text { yoga) }\end{array}$ & & & \\
\hline $\begin{array}{l}\text { Qu, C., et al. } \\
2020 . \\
\text { Functionality } \\
\text { of Top-Rated } \\
\text { Mobile Apps } \\
\text { for } \\
\text { Depression: } \\
\text { Systematic } \\
\text { Search and } \\
\text { Evaluation }\end{array}$ & $\begin{array}{l}\text { United } \\
\text { Kingdom }\end{array}$ & $\begin{array}{l}\text { Quantitat } \\
\text { ive }\end{array}$ & $\begin{array}{l}\text { Systematic } \\
\text { review of } \\
\text { top-rated } \\
\text { mobile apps } \\
\text { for } \\
\text { depression, } \\
\text { with a look } \\
\text { at app } \\
\text { functionalit } \\
\text { y and the } \\
\text { app } \\
\text { intervention } \\
\text { techniques }\end{array}$ & $\begin{array}{l}\text { Currently available apps for } \\
\text { depression provide a wide } \\
\text { array of functionality in } \\
\text { order to help users across a } \\
\text { range of age groups. There } \\
\text { is still the need for } \\
\text { guidelines to ensure that } \\
\text { users' privacy and safety are } \\
\text { protected while using the } \\
\text { apps. This may include } \\
\text { making clear the target } \\
\text { population, or considering } \\
\text { potential risks like non } \\
\text { validated tools and the } \\
\text { expression of negative } \\
\text { emotions. Most of the apps } \\
\text { have evidence based } \\
\text { interventions while a few } \\
\text { apps use clinical input. }\end{array}$ & Yes \\
\hline $\begin{array}{l}\text { Rubanovich, } \\
\text { C. K., et al. } \\
\text { 2017. Health } \\
\text { App Use } \\
\text { Among } \\
\text { Individuals } \\
\text { With } \\
\text { Symptoms of } \\
\text { Depression } \\
\text { and Anxiety: } \\
\text { A Survey } \\
\text { Study With } \\
\text { Thematic } \\
\text { Coding }\end{array}$ & USA & $\begin{array}{l}\text { Qualitati } \\
\text { ve, } \\
\text { survey of } \\
176 \\
\text { people, } \\
\text { largely } \\
\text { white } \\
\text { middle-a } \\
\text { ged } \\
\text { females } \\
\text { from the } \\
\text { Midwest } \\
\text { region of } \\
\text { the US } \\
\text { regarding } \\
\text { the usage } \\
\text { of health } \\
\text { apps. } \\
\text { Participa }\end{array}$ & $\begin{array}{l}\text { Observation } \\
\text { al Study }\end{array}$ & $\begin{array}{l}\text { Over } 3 / 4 \text { (about } 77.8 \% \text { ) of } \\
\text { participants had at least one } \\
\text { of } 285 \text { reported health app } \\
\text { on their devices, with the } \\
\text { top } 3 \text { being exercise, } \\
\text { fitness, and heart rate } \\
\text { monitors ( } 52.8 \% \text { ); diet, } \\
\text { food, or calorie counting } \\
\text { apps ( } 36.9 \%) \text {; and mental } \\
\text { health/wellness apps } \\
(26.1 \%) \text { The mean number } \\
\text { of apps was } 2.15 \text { (SD } \\
3.195) .92 .8 \% \text { of the apps } \\
\text { were free. } 62.6 \% \text { of the } \\
\text { participants reported using } \\
\text { health apps on a daily basis. } \\
\text { Tracking health related data } \\
\text { was the most common } \\
\text { reason for using such apps. }\end{array}$ & Yes \\
\hline
\end{tabular}




\begin{tabular}{|c|c|c|c|c|c|}
\hline & & $\begin{array}{l}\text { nts } \\
\text { complete } \\
\text { d online } \\
\text { questionn } \\
\text { aires on } \\
\text { depressio } \\
\text { n and } \\
\text { anxiety, } \\
\text { mental } \\
\text { health } \\
\text { treatment } \\
\text { seeking } \\
\text { behaviou } \\
\text { r, mobile } \\
\text { device } \\
\text { use, and } \\
\text { use of } \\
\text { mHealth } \\
\text { apps. }\end{array}$ & & $\begin{array}{l}\text { Training and habit building } \\
\text { was the most common } \\
\text { reason for using mental } \\
\text { health apps. }\end{array}$ & \\
\hline $\begin{array}{l}\text { Hartin, P. J., } \\
\text { et al. } 2016 . \\
\text { The } \\
\text { Empowering } \\
\text { Role of } \\
\text { Mobile Apps } \\
\text { in Behavior } \\
\text { Change } \\
\text { Interventions: } \\
\text { The Gray } \\
\text { Matters } \\
\text { Randomized } \\
\text { Controlled } \\
\text { Trial }\end{array}$ & Ireland & $\begin{array}{l}\text { Quantitat } \\
\text { ive; } 102 \\
\text { participa } \\
\text { nts in } \\
\text { experime } \\
\text { ntal } \\
\text { group; } 42 \\
\text { in control } \\
\text { group; } \\
\text { interventi } \\
\text { onal } \\
\text { randomiz } \\
\text { ed } \\
\text { controlle } \\
\text { d trial } \\
\text { with } \\
\text { random } \\
\text { assignme } \\
\text { nt into a } \\
\text { treatment } \\
\text { and } \\
\text { control } \\
\text { group } \\
\text { measurin } \\
\text { g user } \\
\text { behaviou }\end{array}$ & $\begin{array}{l}\text { Randomized } \\
\text { control } \\
\text { trials; } \\
\text { experimenta } \\
1 \text { group used } \\
\text { an app to } \\
\text { encourage } \\
\text { and help } \\
\text { with } \\
\text { behaviour } \\
\text { change to } \\
\text { prevent } \\
\text { Alzheimer's } \\
\text { disease }\end{array}$ & $\begin{array}{l}\text { The app was successful in } \\
\text { being a medium for } \\
\text { intervention. It was able to } \\
\text { use educational intervention } \\
\text { material while also } \\
\text { monitoring and } \\
\text { encouraging positive } \\
\text { behaviour change. } \\
\text { Increased app exposure had } \\
\text { a significant effect on } \\
\text { clinical measurements. }\end{array}$ & Yes \\
\hline
\end{tabular}




\begin{tabular}{|c|c|c|c|c|c|}
\hline & & $\begin{array}{l}\text { r on a } \\
\text { "Gray } \\
\text { Matters" } \\
\text { mobile } \\
\text { app }\end{array}$ & & & \\
\hline $\begin{array}{l}\text { Huberty, J., et } \\
\text { al. } 2019 . \\
\text { Characteristic } \\
\text { s and usage } \\
\text { patterns in a } \\
\text { convenience } \\
\text { sample of } \\
\text { paid } \\
\text { subscribers to } \\
\text { calm } \\
\text { meditation } \\
\text { app: } \\
\text { Cross-section } \\
\text { al survey }\end{array}$ & USA & $\begin{array}{l}\text { Quantitat } \\
\text { ive } \\
\text { survey of } \\
12151 \\
\text { paying } \\
\text { Calm } \\
\text { subscribe } \\
\text { rs } \\
\text { between } \\
18-96 \\
\text { years old. } \\
\text { Question } \\
\text { naires } \\
\text { relating } \\
\text { to user } \\
\text { engagem } \\
\text { ent, } \\
\text { reasons } \\
\text { for using } \\
\text { calm, and } \\
\text { the } \\
\text { effects of } \\
\text { the app. } \\
\text { Sleep } \\
\text { issues, } \\
\text { chronic } \\
\text { health } \\
\text { issues } \\
\text { and } \\
\text { demogra } \\
\text { phics } \\
\text { were also } \\
\text { assessed. }\end{array}$ & $\begin{array}{l}\text { Observation } \\
\text { al Study }\end{array}$ & $\begin{array}{l}\text { The top reason for using } \\
\text { calm is mental health and } \\
\text { sleep issues. The sleep } \\
\text { stories and meditations are } \\
\text { the most popular features of } \\
\text { the app. Findings showed } \\
\text { the frequency of using } \\
\text { Calm was associated with } \\
\text { changes in outcomes. }\end{array}$ & Yes \\
\hline $\begin{array}{l}\text { Iribarren, S. } \\
\text { J., et al. } 2021 . \\
\text { Effectiveness } \\
\text { of Mobile } \\
\text { Apps to } \\
\text { Promote }\end{array}$ & USA & $\begin{array}{l}\text { Quantitat } \\
\text { ive, } \\
\text { literature } \\
\text { search } \\
\text { was } \\
\text { conducte }\end{array}$ & $\begin{array}{l}\text { Systematic } \\
\text { Review and } \\
\text { Meta-analys } \\
\text { is }\end{array}$ & $\begin{array}{l}\text { There is an increase in the } \\
\text { evaluation of apps aimed at } \\
\text { modifying behaviour to } \\
\text { promote health. However, } \\
\text { there is currently low } \\
\text { evidence that these apps }\end{array}$ & Yes \\
\hline
\end{tabular}




\begin{tabular}{|c|c|c|c|c|c|}
\hline $\begin{array}{l}\text { Health and } \\
\text { Manage } \\
\text { Disease: } \\
\text { Systematic } \\
\text { Review and } \\
\text { Meta-analysis } \\
\text { of } \\
\text { Randomized } \\
\text { Controlled } \\
\text { Trials }\end{array}$ & & $\begin{array}{l}\mathrm{d} \text { in } 7 \\
\text { databases } \\
\text {, } \\
\text { extracted } \\
\text { the study } \\
\text { character } \\
\text { istics }\end{array}$ & & $\begin{array}{l}\text { can truly improve health } \\
\text { outcomes. }\end{array}$ & \\
\hline $\begin{array}{l}\text { Mitchell, M., } \\
\text { et al. } 2017 . \\
\text { Uptake of an } \\
\text { Incentive-Bas } \\
\text { ed mHealth } \\
\text { App: Process } \\
\text { Evaluation of } \\
\text { the Carrot } \\
\text { Rewards App }\end{array}$ & Canada & $\begin{array}{l}\text { Quantitat } \\
\text { ive; data } \\
\text { was } \\
\text { collected } \\
\text { over a } 3 \\
\text { month } \\
\text { period; } \\
\text { the data } \\
\text { of } 67 \text {, } \\
464 \text { users } \\
\text { was } \\
\text { analyzed }\end{array}$ & $\begin{array}{l}\text { Observation } \\
\text { al Study }\end{array}$ & $\begin{array}{l}\text { The majority of app users } \\
\text { were female. Findings show } \\
\text { that loyalty points may } \\
\text { promote the usage of } \\
\text { mHealth apps. Therefore, } \\
\text { the use of incentives in } \\
\text { promoting healthy habits is } \\
\text { a possibility for the future. } \\
\text { An issue with mHealth apps } \\
\text { is the development of } \\
\text { personalized interventions } \\
\text { that can help individuals } \\
\text { maintain healthy lifestyles. }\end{array}$ & Yes \\
\hline $\begin{array}{l}\text { Widnall, E., } \\
\text { et al. } 2020 . \\
\text { User } \\
\text { Perspectives } \\
\text { of } \\
\text { Mood-Monit } \\
\text { oring Apps } \\
\text { Available to } \\
\text { Young } \\
\text { People: } \\
\text { Qualitative } \\
\text { Content } \\
\text { Analysis }\end{array}$ & $\begin{array}{l}\text { United } \\
\text { Kingdom }\end{array}$ & $\begin{array}{l}\text { Qualitati } \\
\text { ve } \\
\text { content } \\
\text { analysis; } \\
53 \text { mood } \\
\text { monitori } \\
\text { ng apps } \\
\text { were } \\
\text { analyzed }\end{array}$ & $\begin{array}{l}\text { Systematic } \\
\text { Review }\end{array}$ & $\begin{array}{l}\text { Eight themes discovered in } \\
\text { positive user reviews } \\
\text { include accessibility, } \\
\text { flexibility, recording and } \\
\text { representation of mood, } \\
\text { user requests, reflecting on } \\
\text { mood, technical features, } \\
\text { design and health } \\
\text { promotion. These are likely } \\
\text { to be the main features of } \\
\text { engagement for } \\
\text { mood-monitoring apps } \\
\text { appropriate for young } \\
\text { people under the age of } 18 . \\
\text { Findings show that users } \\
\text { prefer apps that personalize } \\
\text { their needs, have a simple } \\
\text { design, have an accurate } \\
\text { representation and review } \\
\text { of fluctuation moods. The }\end{array}$ & Yes \\
\hline
\end{tabular}




\begin{tabular}{|c|c|c|c|c|c|}
\hline & & & & $\begin{array}{l}\text { reviews on the app store } \\
\text { were found to be a valuable } \\
\text { resource to understand user } \\
\text { engagement feedback. } 20 \% \\
\text { of users see } \\
\text { mood-monitoring apps } \\
\text { positively but also mention } \\
\text { that there is room for } \\
\text { improvement. }\end{array}$ & \\
\hline $\begin{array}{l}\text { Kelly, P. J., et } \\
\text { al. } 2020 . \\
\text { Feasibility of } \\
\text { a Mobile } \\
\text { Health App } \\
\text { for Routine } \\
\text { Outcome } \\
\text { Monitoring } \\
\text { and Feedback } \\
\text { in Mutual } \\
\text { Support } \\
\text { Groups } \\
\text { Coordinated } \\
\text { by SMART } \\
\text { Recovery } \\
\text { Australia: } \\
\text { Protocol for a } \\
\text { Pilot Study }\end{array}$ & Australia & $\begin{array}{l}\text { Mixed-M } \\
\text { ethod: } \\
\text { subjects } \\
\text { receiving } \\
\text { a } \\
\text { nonrando } \\
\text { mized, } \\
\text { prospecti } \\
\text { ve, } \\
\text { single-ar } \\
\text { m trial of } \\
\text { the Smart } \\
\text { Track } \\
\text { app; } 100 \\
\text { participa } \\
\text { nts; } 2 \\
\text { week and } \\
2 \text { month } \\
\text { follow-u } \\
\text { p }\end{array}$ & $\begin{array}{l}\text { Observation } \\
\text { al Study } \\
\text { ROM data } \\
\text { collected } \\
\text { from group } \\
\text { participants } \\
\text { via the } \\
\text { Smart Track } \\
\text { app } \\
\text { Data } \\
\text { analytics } \\
\text { summarizin } \\
\text { g user } \\
\text { interactions } \\
\text { with Smart } \\
\text { Track } \\
\text { Quantitative } \\
\text { interview } \\
\text { and survey } \\
\text { data of } \\
\text { group } \\
\text { participants } \\
\text { (baseline, } \\
\text { 2-week } \\
\text { follow-up, } \\
\text { and } \\
\text { 2-month } \\
\text { follow-up) } \\
\text { Qualitative } \\
\text { interviews } \\
\text { with group } \\
\text { participants } \\
\text { (n=20) and } \\
\text { facilitators } \\
\text { (n=10). }\end{array}$ & $\begin{array}{l}\text { This paper describes a stage } \\
1 \text { pilot study designed to } \\
\text { examine the acceptability of } \\
\text { mHealth routine outcome } \\
\text { monitoring and feedback } \\
\text { app. }\end{array}$ & No \\
\hline
\end{tabular}




\begin{tabular}{|c|c|c|c|c|c|}
\hline $\begin{array}{l}\text { Alam, M. M. } \\
\text { D., et al. } \\
\text { 2021. Factors } \\
\text { influencing } \\
\text { mHealth } \\
\text { adoption and } \\
\text { its impact on } \\
\text { mental } \\
\text { well-being } \\
\text { during } \\
\text { COVID-19 } \\
\text { pandemic: A } \\
\text { SEM-ANN } \\
\text { approach }\end{array}$ & $\begin{array}{l}\text { Banglade } \\
\text { sh }\end{array}$ & $\begin{array}{l}\text { Mixed } \\
\text { Method }\end{array}$ & $\begin{array}{l}\text { Observation } \\
\text { al Study }\end{array}$ & $\begin{array}{l}\text { Performance expectancy, } \\
\text { effort expectancy, social } \\
\text { influence, hedonic } \\
\text { motivation and facilitating } \\
\text { conditions have a positive } \\
\text { effect on the behavioural } \\
\text { intention. Health } \\
\text { consciousness has an effect } \\
\text { on intention to use and } \\
\text { actual usage behaviour as } \\
\text { well. Overall, the use of } \\
\text { mHealth based } \\
\text { interventions has a } \\
\text { meaningful impact on the } \\
\text { mental well-being of its } \\
\text { users. }\end{array}$ & No \\
\hline $\begin{array}{l}\text { Tuarob, S., et } \\
\text { al. } 2017 . \\
\text { How are you } \\
\text { feeling?: A } \\
\text { personalized } \\
\text { methodology } \\
\text { for predicting } \\
\text { mental states } \\
\text { from } \\
\text { temporally } \\
\text { observable } \\
\text { physical and } \\
\text { behavioral } \\
\text { information }\end{array}$ & USA & $\begin{array}{l}\text { Mixed } \\
\text { Method } \\
\text { machine } \\
\text { learning } \\
\text { system to } \\
\text { predict } \\
\text { user } \\
\text { mental } \\
\text { states }\end{array}$ & $\begin{array}{l}\text { Observation } \\
\text { al Study } \\
\text { Questionnai } \\
\text { re to } \\
\text { measure } \\
\text { attributes to } \\
\text { represent } \\
\text { measures of } \\
\text { mental and } \\
\text { physical } \\
\text { conditions } \\
\text { of human } \\
\text { participants } \\
\text { (e.g. hours } \\
\text { of sleep) }\end{array}$ & $\begin{array}{l}\text { The study is a first step in } \\
\text { developing medical } \\
\text { applications that could } \\
\text { automatically gauge the } \\
\text { mental state of individuals. }\end{array}$ & No \\
\hline $\begin{array}{l}\text { Wasil, A. R., } \\
\text { et al. } 2020 . \\
\text { Reassessing } \\
\text { evidence-bas } \\
\text { ed content in } \\
\text { popular } \\
\text { smartphone } \\
\text { apps for } \\
\text { depression } \\
\text { and anxiety: } \\
\text { Developing } \\
\text { and applying } \\
\text { user-adjusted }\end{array}$ & USA & $\begin{array}{l}\text { Mixed } \\
\text { method }\end{array}$ & $\begin{array}{l}\text { Observation } \\
\text { al Study }\end{array}$ & $\begin{array}{l}\text { Mental health apps' impact } \\
\text { on mental health may be } \\
\text { best evaluated through a } \\
\text { combined tally of } \\
\text { evidence-based content } \\
\text { with data on the content } \\
\text { users are actually accessing. } \\
\text { Given wide variation in the } \\
\text { popularity of MH apps, } \\
\text { findings weighted by usage } \\
\text { data may differ markedly } \\
\text { from findings based on raw } \\
\text { tallies alone. }\end{array}$ & Yes \\
\hline
\end{tabular}




\begin{tabular}{|c|c|c|c|c|c|}
\hline analyses & & & & $\begin{array}{l}\text { The top } 2 \text { apps on Apple } \\
\text { store and Play store had } \\
90 \% \text { of the monthly active } \\
\text { users. } 37 \% \text { of all mental } \\
\text { health apps included } \\
\text { mindfulness but it reached } \\
96 \% \text { of mental health app } \\
\text { users; } 22 \% \text { of apps had } \\
\text { cognitive restructuring } \\
\text { interventions but it only } \\
\text { reached } 2 \% \text { of its users; } 7 \% \\
\text { of apps had exposure but it } \\
\text { reached only } 0.0004 \% \text { of } \\
\text { the users }\end{array}$ & \\
\hline $\begin{array}{l}\text { Dennison, L., } \\
\text { et al. } 2013 \text {. } \\
\text { Opportunities } \\
\text { and } \\
\text { Challenges } \\
\text { for } \\
\text { Smartphone } \\
\text { Applications } \\
\text { in Supporting } \\
\text { Health } \\
\text { Behavior } \\
\text { Change: } \\
\text { Qualitative } \\
\text { Study }\end{array}$ & $\begin{array}{l}\text { United } \\
\text { Kingdom }\end{array}$ & $\begin{array}{l}\text { Qualitati } \\
\text { ve; } 19 \\
\text { universit } \\
\text { y } \\
\text { students } \\
\text { and staffs } \\
\text { participat } \\
\text { ed in } 4 \\
\text { focus } \\
\text { groups }\end{array}$ & $\begin{array}{l}\text { Observation } \\
\text { al Study }\end{array}$ & $\begin{array}{l}\text { Participants believed that } \\
\text { accuracy and legitimacy, } \\
\text { security, effort required, } \\
\text { and immediate effects on } \\
\text { mood would affect their app } \\
\text { usage, as well as the ability } \\
\text { to record and track behavior } \\
+ \text { goals and learn new } \\
\text { information.There is some } \\
\text { interest in using apps that } \\
\text { support health-related } \\
\text { behaviour change. Context } \\
\text { sensing and social media } \\
\text { features were perceived } \\
\text { negatively. }\end{array}$ & Yes \\
\hline $\begin{array}{l}\text { Kennedy, C. } \\
\text { M., et al. } \\
\text { 2012. Active } \\
\text { Assistance } \\
\text { Technology } \\
\text { for } \\
\text { Health-Relate } \\
\text { d Behavior } \\
\text { Change: An } \\
\text { Interdisciplin } \\
\text { ary Review }\end{array}$ & $\begin{array}{l}\text { United } \\
\text { Kingdom }\end{array}$ & $\begin{array}{l}\text { Qualitati } \\
\text { ve } \\
\text { interdisci } \\
\text { plinary } \\
\text { literature } \\
\text { review }\end{array}$ & $\begin{array}{l}\text { Literature } \\
\text { review }\end{array}$ & $\begin{array}{l}\text { There are potential risks } \\
\text { and capabilities of assistant } \\
\text { technologies that still need } \\
\text { to be explored in the } \\
\text { behaviour change research. } \\
\text { How dynamic and adaptive } \\
\text { information processing is } \\
\text { being used for behavior } \\
\text { change interventions }\end{array}$ & Yes \\
\hline $\begin{array}{l}\text { Zhao, J., et } \\
\text { al. 2016. Can }\end{array}$ & Australia & $\begin{array}{l}\text { Quantitat } \\
\text { ive }\end{array}$ & $\begin{array}{l}\text { Literature } \\
\text { Review }\end{array}$ & $\begin{array}{l}\text { Some features make apps } \\
\text { better, such as less time }\end{array}$ & Yes \\
\hline
\end{tabular}




\begin{tabular}{|c|c|c|c|c|c|}
\hline $\begin{array}{l}\text { Mobile } \\
\text { Phone Apps } \\
\text { Influence } \\
\text { People's } \\
\text { Health } \\
\text { Behavior } \\
\text { Change? An } \\
\text { Evidence } \\
\text { Review }\end{array}$ & & $\begin{array}{l}\text { evidence } \\
\text { review; } \\
41 \\
\text { articles } \\
\text { included } \\
\text { in the } \\
\text { review }\end{array}$ & $\begin{array}{l}\text { Studies that } \\
\text { report } \\
\text { statistically } \\
\text { significant } \\
\text { effects } \\
\text { towards } \\
\text { behavior } \\
\text { change }\end{array}$ & $\begin{array}{l}\text { consumption, user-friendly } \\
\text { design, real-time feedback, } \\
\text { individualized elements, } \\
\text { detailed information, and } \\
\text { health professional } \\
\text { involvement. } \\
\text { Empathy and relational } \\
\text { behaviour are major } \\
\text { research themes for } \\
\text { behaviour change research. } \\
\text { These factors have been } \\
\text { shown to have a positive } \\
\text { effect on behaviour. } \\
\text { However, it was found that } \\
\text { too much interaction can } \\
\text { inhibit positive health } \\
\text { behaviours. The review also } \\
\text { found that there are not } \\
\text { many interventions } \\
\text { focusing on dynamic } \\
\text { tailoring, interactive } \\
\text { education, and } \\
\text { self-monitoring. }\end{array}$ & \\
\hline $\begin{array}{l}\text { Hicks, J. L., } \\
\text { et al. } 2019 . \\
\text { Best practices } \\
\text { for analyzing } \\
\text { large-scale } \\
\text { health data } \\
\text { from } \\
\text { wearables } \\
\text { and } \\
\text { smartphone } \\
\text { apps }\end{array}$ & USA & $\begin{array}{l}\text { Qualitati } \\
\text { ve }\end{array}$ & $\begin{array}{l}\text { Observation } \\
\text { al Study }\end{array}$ & $\begin{array}{l}\text { Majority of users- } 75 \% \text { - } \\
\text { re-engage with apps after } \\
\text { extended periods of } \\
\text { dormancy. The health status } \\
\text { of these users after } \\
\text { re-engagement returned to } \\
\text { the same as when they first } \\
\text { started using the app. Users } \\
\text { were categorized on their } \\
\text { app usage into occasional, } \\
\text { basic and power users. } \\
\text { Power users showed the } \\
\text { most changes. For social } \\
\text { network challenges and } \\
\text { competitions, findings show } \\
\text { that men are affected by the } \\
\text { performance of other men } \\
\text { and women, but women are } \\
\text { affected only by the } \\
\text { performance of other } \\
\text { women. Users were also }\end{array}$ & Yes \\
\hline
\end{tabular}




\begin{tabular}{|c|c|c|c|c|c|}
\hline & & & & $\begin{array}{l}\text { more likely to lose weight } \\
\text { when they more networks } \\
\text { with members of the } \\
\text { opposite sex. }\end{array}$ & \\
\hline $\begin{array}{l}\text { Anderson, K., } \\
\text { et al. } 2016 . \\
\text { Mobile } \\
\text { Health Apps } \\
\text { to Facilitate } \\
\text { Self-Care: A } \\
\text { Qualitative } \\
\text { Study of User } \\
\text { Experiences }\end{array}$ & Australia & $\begin{array}{l}\text { Qualitati } \\
\text { ve Study; } \\
22 \\
\text { participa } \\
\text { nts who } \\
\text { used } \\
\text { Health } \\
\text { apps }\end{array}$ & $\begin{array}{l}\text { Observation } \\
\text { al Study; } \\
\text { semi-structu } \\
\text { red } \\
\text { interviews. } \\
\text { Apps } \\
\text { monitored } \\
\text { diabetes, } \\
\text { asthma, } \\
\text { depression, } \\
\text { celiac } \\
\text { disease, } \\
\text { blood } \\
\text { pressure, } \\
\text { chronic } \\
\text { migraine, } \\
\text { pain } \\
\text { managemen } \\
\text { t, menstrual } \\
\text { cycle } \\
\text { irregularity, } \\
\text { and fitness. }\end{array}$ & $\begin{array}{l}\text { Findings show that } \\
\text { self-management can be } \\
\text { improved through the use } \\
\text { of health apps for chronic } \\
\text { conditions. However, } \\
\text { self-management through } \\
\text { apps requires constant } \\
\text { stimulation to } \\
\text { accommodate changing } \\
\text { requirements and } \\
\text { well-being. Some users } \\
\text { with chronic conditions } \\
\text { such as diabetes, } \\
\text { depression, weight and } \\
\text { sleep management issues } \\
\text { were recommended only } \\
\text { fitness apps and not disease } \\
\text { specific apps. Benefits of } \\
\text { using gamification have } \\
\text { also been reported. }\end{array}$ & Yes \\
\hline $\begin{array}{l}\text { Aydin, G., \& } \\
\text { Silahtaroglu, } \\
\text { G. } 2021 . \\
\text { Insights into } \\
\text { mobile health } \\
\text { application } \\
\text { market via a } \\
\text { content } \\
\text { analysis of } \\
\text { marketplace } \\
\text { data with } \\
\text { machine } \\
\text { learning }\end{array}$ & Turkey & $\begin{array}{l}\text { Quantitat } \\
\text { ive; } \\
\text { investigat } \\
\text { ing } 1000 \\
\text { apps }\end{array}$ & $\begin{array}{l}\text { Observation } \\
\text { al Study }\end{array}$ & $\begin{array}{l}\text { The findings suggest that } \\
\text { apps that mention a privacy } \\
\text { policy or provide videos in } \\
\text { description lead to higher } \\
\text { user scores, whereas free } \\
\text { apps with in-app purchase } \\
\text { possibilities, social } \\
\text { networking and sharing } \\
\text { features and feedback } \\
\text { mechanisms lead to higher } \\
\text { number of downloads. }\end{array}$ & Yes \\
\hline $\begin{array}{l}\text { Champion, } \\
\text { L., et al. } \\
\text { 2018. The } \\
\text { efficacy of a }\end{array}$ & $\begin{array}{l}\text { United } \\
\text { Kingdom }\end{array}$ & $\begin{array}{l}\text { Quantitat } \\
\text { ive } \\
\text { randomiz } \\
\text { ed }\end{array}$ & $\begin{array}{l}\text { Randomized } \\
\text { Control } \\
\text { Study; } \\
\text { Experiment }\end{array}$ & $\begin{array}{l}\text { The use of the mindfulness } \\
\text { meditation app (MM) } \\
\text { "Headspace" led to positive } \\
\text { satisfaction with life, stress, }\end{array}$ & Yes \\
\hline
\end{tabular}




\begin{tabular}{|c|c|c|c|c|c|}
\hline $\begin{array}{l}\text { brief } \\
\text { app-based } \\
\text { mindfulness } \\
\text { intervention } \\
\text { on } \\
\text { psychosocial } \\
\text { outcomes in } \\
\text { healthy } \\
\text { adults: A } \\
\text { pilot } \\
\text { randomised } \\
\text { controlled } \\
\text { trial }\end{array}$ & & $\begin{array}{l}\text { controlle } \\
\text { d trial of } \\
38 \\
\text { students } \\
\text { for } \\
\text { experime } \\
\text { ntal } \\
\text { group } \\
\text { and } 36 \\
\text { for } \\
\text { control } \\
\text { group. } \\
\text { Study } \\
\text { was done } \\
\text { for a } \\
\text { period of } \\
10 \text { or } 30 \\
\text { days. }\end{array}$ & al study & $\begin{array}{l}\text { and resilience, and } \\
\text { protected against perceived } \\
\text { stress by the 10th day. } \\
\text { There were more } \\
\text { improvements by the } 30 \text { th } \\
\text { day. } \\
\text { The rate of improvement } \\
\text { was the highest on the } 10 \text { th } \\
\text { day as well and dropped by } \\
\text { the } 30 \text { th day. Users that } \\
\text { found the app the easiest to } \\
\text { interact with had the } \\
\text { highest self-reported } \\
\text { benefits. }\end{array}$ & \\
\hline $\begin{array}{l}\text { Cor, E., \& } \\
\text { Zwolinski, P. } \\
\text { 2014. A } \\
\text { Procedure to } \\
\text { Define the } \\
\text { Best Design } \\
\text { Intervention } \\
\text { Strategy on a } \\
\text { Product for a } \\
\text { Sustainable } \\
\text { Behavior of } \\
\text { the User }\end{array}$ & France & $\begin{array}{l}\text { Mixed } \\
\text { method; } \\
\text { the } \\
\text { energy } \\
\text { and water } \\
\text { consumpt } \\
\text { ion } \\
\text { during } \\
\text { the use } \\
\text { phase of } \\
36 \\
\text { espresso } \\
\text { coffee } \\
\text { machine } \\
\text { users } \\
\text { were } \\
\text { measured } \\
\text {, as well } \\
\text { as } \\
\text { environm } \\
\text { ental } \\
\text { knowled } \\
\text { ge, } \\
\text { attitude, } \\
\text { and } \\
\text { habits }\end{array}$ & $\begin{array}{l}\text { Experiment } \\
\text { al user data } \\
\text { measured } \\
\text { from the use } \\
\text { of coffee } \\
\text { machines } \\
\text { experiencin } \\
\text { g different } \\
\text { design } \\
\text { intervention } \\
\text { strategies }\end{array}$ & $\begin{array}{l}\text { The environmental impacts } \\
\text { slowly decrease with new } \\
\text { usage of the product. }\end{array}$ & No \\
\hline
\end{tabular}




\begin{tabular}{|c|c|c|c|c|c|}
\hline $\begin{array}{l}\text { Lee, S. K. A. } \\
2018 . \\
\text { Classification } \\
\text { of } \\
\text { SmartMental } \\
\text { Tech Services } \\
\text { and } \\
\text { Application } \\
\text { for } \\
\text { Comprehensi } \\
\text { ve Mental } \\
\text { Healthcare } \\
\text { Stepped-Care } \\
\text { Model } \\
\text { (CMHSCM): } \\
\text { Health } \\
\text { Psychological } \\
\text { Approach }\end{array}$ & Japan & $\begin{array}{l}\text { Quantitat } \\
\text { ive } \\
\text { research } \\
\text { method } \\
\text { through } \\
\text { distributi } \\
\text { on of a } \\
\text { QR code } \\
\text { to } \\
\text { SmartMe } \\
\text { ntalTech } \\
\text { users; } \\
\text { 264 } \\
\text { participa } \\
\text { nts; } 2 \\
\text { months } \\
\text { duration }\end{array}$ & $\begin{array}{l}\text { Observation } \\
\text { al Study } \\
\text { Survey } \\
\text { questionnair } \\
\text { e data }\end{array}$ & $\begin{array}{l}\text { SmartMentalTech can be } \\
\text { used as a readily accessible } \\
\text { user technology, especially } \\
\text { in locations like South } \\
\text { Korea and Japan where } \\
\text { traditional mental health } \\
\text { systems are not accessible } \\
\text { due to social stigma. Apps } \\
\text { like this can be used as } \\
\text { interventions for mental } \\
\text { health problems until } \\
\text { professional help can be } \\
\text { substituted. Additionally, it } \\
\text { can influence caregivers' } \\
\text { decisions to implement the } \\
\text { tech in a stepped-care } \\
\text { system. } \\
\text { South korean participants } \\
\text { preferred wearable devices, } \\
\text { big data, AI and robots. Big } \\
\text { data and e therapy were } \\
\text { preferred by Japanese. } \\
\text { Findings show that users do } \\
\text { not know the best } \\
\text { technology for their } \\
\text { problems. Overall, the } \\
\text { study claims that Smart } \\
\text { Mental Health Technology } \\
\text { needs to be promoted as a } \\
\text { readily accessible solution } \\
\text { for users. }\end{array}$ & Yes \\
\hline $\begin{array}{l}\text { Almeida, A. } \\
\text { M. P., et al. } \\
\text { 2018. Mobile } \\
\text { solutions in } \\
\text { depression: } \\
\text { enhancing } \\
\text { communicati } \\
\text { on with } \\
\text { patients using } \\
\text { an } \\
\text { SMS-based } \\
\text { intervention }\end{array}$ & Portugal & $\begin{array}{l}\text { Qualitati } \\
\text { ve } \\
\text { research } \\
\text { method } \\
\text { testing a } \\
\text { Short } \\
\text { Message } \\
\text { Service } \\
\text { (SMS) } \\
\text { method } \\
\text { to } \\
\text { improve } \\
\text { communi } \\
\text { cation }\end{array}$ & $\begin{array}{l}\text { Observation } \\
\text { al Study }\end{array}$ & $\begin{array}{l}\text { There is a demand for } \\
\text { improving clinical } \\
\text { communication between } \\
\text { patients and health } \\
\text { professionals, and mobile } \\
\text { solutions like SMSs can } \\
\text { help patients with } \\
\text { depression access } \\
\text { personalized interventions. } \\
\text { However, personal support } \\
\text { and contact should be used } \\
\text { in conjunction with these } \\
\text { digital tools. } \\
\text { The study claims that }\end{array}$ & Yes \\
\hline
\end{tabular}




\begin{tabular}{|c|c|c|c|c|c|}
\hline & & $\begin{array}{l}\text { with } \\
\text { patients } \\
\text { that have } \\
\text { depressio } \\
\text { n. There } \\
\text { were } 4 \\
\text { stages; } \\
\text { 1st stage } \\
\text { had 36 } \\
\text { patients } \\
\text { and 11 } \\
\text { health } \\
\text { professio } \\
\text { nals; } \\
\text { stage } 2 \\
\text { had } 15 \\
\text { patients } \\
\text { with } \\
\text { depressio } \\
\text { n; stage } 3 \\
\text { had } 143 \\
\text { physician } \\
\text { s. }\end{array}$ & & $\begin{array}{l}\text { complementary approaches } \\
\text { that allow better } \\
\text { communication between } \\
\text { physicians and patients are } \\
\text { useful. The pairing of } \\
\text { mobile interventions and } \\
\text { face-to-face support is } \\
\text { beneficial. }\end{array}$ & \\
\hline $\begin{array}{l}\text { Shafinah, K., } \\
\text { et al. } 2013 . \\
\text { Determinants } \\
\text { of User } \\
\text { Behavior } \\
\text { Intention (BI) } \\
\text { on Mobile } \\
\text { Services: A } \\
\text { Preliminary } \\
\text { View }\end{array}$ & Malaysia & $\begin{array}{l}\text { Qualitati } \\
\text { ve } \\
\text { experime } \\
\text { nt }\end{array}$ & $\begin{array}{l}\text { Methodolog } \\
\text { y }\end{array}$ & $\begin{array}{l}\text { The most important factors } \\
\text { for mHealth applications } \\
\text { are the ease of use, cost, } \\
\text { risk/security, and trust. }\end{array}$ & No \\
\hline $\begin{array}{l}\text { Clough, B. } \\
\text { A., \& Casey, } \\
\text { L. M. } 2015 \text {. } \\
\text { Smart } \\
\text { designs for } \\
\text { smart } \\
\text { technologies: } \\
\text { Research } \\
\text { challenges } \\
\text { and emerging } \\
\text { solutions for }\end{array}$ & Australia & $\begin{array}{l}\text { Mixed } \\
\text { methods }\end{array}$ & $\begin{array}{l}\text { Methodolog } \\
\text { y, Single } \\
\text { Case } \\
\text { Research } \\
\text { (SCR) } \\
\text { design }\end{array}$ & $\begin{array}{l}\text { No outcomes relevant to } \\
\text { our research question. The } \\
\text { development of e-mental } \\
\text { health requires a greater } \\
\text { diversity of flexible, } \\
\text { time-effective research } \\
\text { designs. These strategies } \\
\text { within this paper can help } \\
\text { patients receive mental } \\
\text { health interventions that are } \\
\text { backed with evidence, as }\end{array}$ & No \\
\hline
\end{tabular}




\begin{tabular}{|c|c|c|c|c|c|}
\hline $\begin{array}{l}\text { scientist-pract } \\
\text { itioners } \\
\text { within } \\
\text { e-mental } \\
\text { health }\end{array}$ & & & & $\begin{array}{l}\text { well as a variety of } \\
\text { treatment methods (e.g. } \\
\text { CBT, acceptance and } \\
\text { commitment therapy, } \\
\text { depression, anxiety, } \\
\text { substance use). }\end{array}$ & \\
\hline $\begin{array}{l}\text { Clough, B. } \\
\text { A., \& Casey, } \\
\text { L. M. } 2015 \text {. } \\
\text { The smart } \\
\text { therapist: A } \\
\text { look to the } \\
\text { future of } \\
\text { smartphones } \\
\text { and mHealth } \\
\text { technologies } \\
\text { in } \\
\text { psychotherap } \\
\text { y }\end{array}$ & Australia & $\begin{array}{l}\text { Qualitati } \\
\text { ve }\end{array}$ & $\begin{array}{l}\text { Literature } \\
\text { Review }\end{array}$ & $\begin{array}{l}\text { Findings show that users } \\
\text { want to engage in mHealth } \\
\text { interventions, however } \\
\text { there is only a limited } \\
\text { number of evidence based } \\
\text { mHealth interventions. } \\
\text { SMS have been shown to } \\
\text { have a positive effect on the } \\
\text { continuation of treatment } \\
\text { benefits once the treatment } \\
\text { program is finished. } \\
\text { Ecological momentary } \\
\text { assessment techniques also } \\
\text { show high rates of } \\
\text { acceptability and feasibility } \\
\text { for interventions. }\end{array}$ & Yes \\
\hline $\begin{array}{l}\text { Marshall, J. } \\
\text { M., et al. } \\
2020 . \\
\text { Smartphone } \\
\text { psychology: } \\
\text { New } \\
\text { approaches } \\
\text { towards safe } \\
\text { and } \\
\text { efficacious } \\
\text { mobile } \\
\text { mental health } \\
\text { apps }\end{array}$ & Australia & $\begin{array}{l}\text { Qualitati } \\
\text { ve, } \\
\text { involves } \\
\text { the } \\
\text { proposal } \\
\text { of a new } \\
\text { approach } \\
\text { to } \\
\text { incorpora } \\
\text { te } \\
\text { multiple } \\
\text { baseline } \\
\text { single-ca } \\
\text { se } \\
\text { designs } \\
\text { to guide } \\
\text { larger-sca } \\
\text { le } \\
\text { randomiz } \\
\text { ed } \\
\text { controlle } \\
\text { d trials }\end{array}$ & $\begin{array}{l}\text { Literature } \\
\text { Review }\end{array}$ & $\begin{array}{l}\text { The dependency of current } \\
\text { research on the ratings and } \\
\text { reviews from the } \\
\text { application stores is not } \\
\text { reliable. There are also a lot } \\
\text { of mental health apps that } \\
\text { don't derive their } \\
\text { interventions from evidence } \\
\text { based psychology that can } \\
\text { be ineffective and harmful. } \\
\text { There exists a need for } \\
\text { mental health app users to } \\
\text { be able to identify safe and } \\
\text { effective solutions. Thus, } \\
\text { research into effectiveness } \\
\text { and safety needs become } \\
\text { more visible. }\end{array}$ & Yes \\
\hline
\end{tabular}




\begin{tabular}{|c|c|c|c|c|c|}
\hline $\begin{array}{l}\text { Fuentes-Blas } \\
\text { co, M., et al. } \\
2014 \text {. Effect } \\
\text { of customer } \\
\text { heterogeneity } \\
\text { on the } \\
\text { relationship } \\
\text { satisfaction-1 } \\
\text { oyalty }\end{array}$ & Spain & $\begin{array}{l}\text { Mixed } \\
\text { method, } \\
\text { analyze } \\
\text { heteroge } \\
\text { neous } \\
\text { shopping } \\
\text { patterns } \\
\text { with } \\
\text { statistical } \\
\text { methods }\end{array}$ & $\begin{array}{l}\text { A } \\
\text { quantitative } \\
\text { investigatio } \\
\mathrm{n} \text { and } \\
\text { questionnair } \\
\mathrm{e}\end{array}$ & $\begin{array}{l}\text { Study is not relevant to our } \\
\text { research question. The } \\
\text { paper discusses customer } \\
\text { behaviour in retail settings. }\end{array}$ & No \\
\hline $\begin{array}{l}\text { Bailon, C., et } \\
\text { al. } 2019 . \\
\text { Smartphone- } \\
\text { Based } \\
\text { Platform for } \\
\text { Affect } \\
\text { Monitoring } \\
\text { through } \\
\text { Flexibly } \\
\text { Managed } \\
\text { Experience } \\
\text { Sampling } \\
\text { Methods }\end{array}$ & Spain & $\begin{array}{l}\text { Mixed } \\
\text { method, } \\
\text { analyze } \\
\text { the time } \\
\text { of } \\
\text { questionn } \\
\text { aire } \\
\text { response } \\
\text { as well as } \\
\text { the } \\
\text { affective } \\
\text { states of } \\
\text { app users }\end{array}$ & $\begin{array}{l}\text { Observation } \\
\text { al study }\end{array}$ & $\begin{array}{l}\text { Study is not relevant to our } \\
\text { research question. The } \\
\text { response rate to surveys } \\
\text { about affective states } \\
\text { increases throughout the } \\
\text { day, as does the amount of } \\
\text { time participants take to } \\
\text { open the survey. The app } \\
\text { tested in this experiment is } \\
\text { highly usable as a result of } \\
\text { good user interface and } \\
\text { accessible app options. }\end{array}$ & No \\
\hline $\begin{array}{l}\text { Lin, X., \& } \\
\text { Kishore, R. } \\
\text { 2021. Social } \\
\text { media-enable } \\
\text { d healthcare: } \\
\text { A conceptual } \\
\text { model of } \\
\text { social media } \\
\text { affordances, } \\
\text { online social } \\
\text { support, and } \\
\text { health } \\
\text { behaviors and } \\
\text { outcomes }\end{array}$ & USA & $\begin{array}{l}\text { Qualitati } \\
\text { ve }\end{array}$ & $\begin{array}{l}\text { Literature } \\
\text { Review }\end{array}$ & $\begin{array}{l}\text { The paper suggests that } \\
\text { there are three different } \\
\text { types of social support: } \\
\text { informational support, } \\
\text { emotional support, and } \\
\text { experiential support. Social } \\
\text { media fosters social } \\
\text { support; User interaction } \\
\text { fosters emotional support; } \\
\text { social learning fosters } \\
\text { experiential support. } \\
\text { Self-care is impacted by } \\
\text { informational support and } \\
\text { experiential support. } \\
\text { Psychological health is } \\
\text { affected by informational } \\
\text { and emotional support. }\end{array}$ & Yes \\
\hline $\begin{array}{l}\text { Iowa State } \\
\text { University. } \\
\text { 2015. Mobile }\end{array}$ & USA & $\begin{array}{l}\text { Qualitati } \\
\text { ve }\end{array}$ & $\begin{array}{l}\text { Science } \\
\text { Daily News } \\
\text { article }\end{array}$ & $\begin{array}{l}\text { More than half of apps } \\
\text { downloaded are deleted } \\
\text { after one use, making first }\end{array}$ & Yes \\
\hline
\end{tabular}




\begin{tabular}{|c|c|c|c|c|c|}
\hline $\begin{array}{l}\text { apps and } \\
\text { online } \\
\text { reviews } \\
\text { influence } \\
\text { consumer } \\
\text { behavior }\end{array}$ & & & & $\begin{array}{l}\text { impressions an important } \\
\text { feature. Product reviews } \\
\text { and social media posts have } \\
\text { an impact on the perception } \\
\text { of apps and their brand. }\end{array}$ & \\
\hline $\begin{array}{l}\text { Common } \\
\text { Sense. } 2021 . \\
\text { Coping with } \\
\text { COVID-19: } \\
\text { How Young } \\
\text { People Use } \\
\text { Digital Media } \\
\text { to Manage } \\
\text { Their Mental } \\
\text { Health }\end{array}$ & USA & $\begin{array}{l}\text { Mixed-m } \\
\text { ethod }\end{array}$ & $\begin{array}{l}\text { Common } \\
\text { sense media } \\
\text { report }\end{array}$ & $\begin{array}{l}\text { No outcomes relevant to } \\
\text { our research question }\end{array}$ & No \\
\hline $\begin{array}{l}\text { Extreme } \\
\text { Marketing } \\
\text { Team. } 2021 . \\
\text { Mobile User } \\
\text { Engagement } \\
\text { Apps - } \\
\text { Trends and } \\
\text { Requirements }\end{array}$ & $\mathrm{N} / \mathrm{A}$ & $\begin{array}{l}\text { Mixed-m } \\
\text { ethod }\end{array}$ & $\begin{array}{l}\text { Extreme } \\
\text { network } \\
\text { news article }\end{array}$ & $\begin{array}{l}\text { The most desirable feature } \\
\text { for apps are those that } \\
\text { involve information } \\
\text { sharing. }\end{array}$ & No \\
\hline $\begin{array}{l}\text { Nilsson, B. } \\
\text { 2018. How } \\
\text { apps can } \\
\text { increase } \\
\text { student } \\
\text { engagement }\end{array}$ & N/A & $\begin{array}{l}\text { Qualitati } \\
\text { ve }\end{array}$ & $\begin{array}{l}\text { ecampus } \\
\text { news article }\end{array}$ & $\begin{array}{l}\text { Information sharing is the } \\
\text { most desirable feature for } \\
\text { apps. }\end{array}$ & No \\
\hline $\begin{array}{l}\text { O’Dowd, E. } \\
\text { 2017. How to } \\
\text { Build a } \\
\text { Successful } \\
\text { Healthcare } \\
\text { Mobility } \\
\text { Solution }\end{array}$ & N/A & $\begin{array}{l}\text { Qualitati } \\
\text { ve }\end{array}$ & $\begin{array}{l}\text { Hit } \\
\text { Infrastructur } \\
\text { e news } \\
\text { article }\end{array}$ & $\begin{array}{l}\text { No outcomes relevant to } \\
\text { our research question }\end{array}$ & No \\
\hline
\end{tabular}

